If you do not need this publication after it has served your purpose, please return it to the Geological Survey, using the offeial mailing label st the enc

UNITED STATES DEPARTMENT OF THE INTERIOR

SOME LINGULOID SHELLS FROM THE LATE DEVONIAN AND EARLY CARBONIFEROUS ROCKS OF PENNSYLVANIA AND OHIO

GEOLOGICAL SURVEY PROFESSIONAL PAPER 193-C 

UNITED STATES DEPARTMENT OF THE INTERIOR

Harold L. Ickes, Secretary

GEOLOGICAL SURVEY

W. C. Mendenhall, Director

Professional Paper 193-C

\title{
SOME LINGULOID SHELLS FROM THE LATE DEVONIAN AND EARLY GARBONIFEROUS ROGKS OF PENNSYLVANIA AND OHIO
}

BY

\author{
GEORGE H. GIRTY
}

Shorter contributions to general geology, 1938-39

(Pages 47-67)

UNITED STATFS

GOVERNMENT PRINTING OFFICE

WASHINGTON : 1939

For sale by the Superintendent of Documents, Washington, D. C. - - - - - - - - - - - Price 10 cents 


\section{CONTENTS}

Introduction

Systematic descriptions

Genus Lingula Bruguière . . . . .

Genus Trigonoglossa Dunbar and Condra.

.

\section{ILLUSTRATION}

Plate 9. Late Devonian and early Carboniferous linguloids 


\title{
SOME LINGULOID SHELLS FROM THE LATE DEVONIAN AND EARLY CARBONIFEROUS ROCKS OF PENNSYLVANIA AND OHIO
}

\author{
By George H. Girty
}

\section{INTRODUCTION}

In the closing years of the last century I spent considerable time in Ohio collecting from the †Waverly rocks ${ }^{1}$ and studying their faunas. Somewhat later, at the suggestion, as I recall, of M. R. Campbell, I crossed the State line and did some work in northwestern Pennsylvania. As that work progressed it became clear that there was a series of rocks about 500 feet in thickness which was unrepresented by name in the geologic time scale.

When the term "Kinderhook" was proposed for the oldest unit of the Carboniferous in this country, the tWaverly group of Ohio was explicitly included in the Kinderhook, along with the typical Kinderhook rocks of the Mississippi Valley. On the other hand, the Chemung of the New York section was, I believe universally, recognized as the final unit of the Devonian. The work of I. C. White in Crawford and Erie Counties, Pa., had established the fact that between the Chemung, as he recognized it, and the base of the tWaverly group in Ohio there were several intervening formations. For this interval I introduced the name "†Bradfordian series." Some of the things which at that time I proposed to do were (1) to check White's identification of the Chemung in northwestern Pennsylvania, (2) to determine the base of the Mississippian in terms of the typical Kinderhook of the Mississippi Valley, and (3) to describe the faunas of the †Bradfordian rocks. It became evident to me before very long that to carry out these objectives would require the concentrated effort of many years, and the realization of this fact, together with the intervention of other duties and other interests, led me gradually, if reluctantly, to abandon those purposes.

I did, however, prove to my own satisfaction that the probable base of the Mississippian in Pennsylvania in terms of the Mississippian type section is the Corry sandstone, which is correlative in a general way with the Berea sandstone in Ohio, and I made a start in describing the faunas of the †Bradfordian beds. The present small paper is part of that descriptive work. The descriptions have, of course, been revised, and a few †Waverly species have been added that seemed

1 A dagger $(\dagger)$ preceding a geologic name indicates that the name has been abandoned or rejected for use in classification in publications of the Geological Survey. to be interesting or germane to the general subject. Several of the species discussed are definitely of Carboniferous age, and some if not all of the others are probably Devonian.

Regarding the third of my original objectives, toward which I had made no appreciable advance, I may add that the work of several able geologists has shown that the typical Chemung of New York occurs in northwestern Pennsylvania at a horizon considerably below the Chemung of White. Obviously, the †Bradfordian series in its original conception would extend below White's Chemung to the true Chemung of Chemung Narrows, New York, and to its correlative in northwestern Pennsylvania.

Grateful acknowledgments are due to the United States National Museum for the use of collections, especially the extensive Randall collection, covering many localities in the vicinity of Warren and elsewhere in northwestern Pennsylvania.

Acknowledgments are also due to my friend, Wilbur Stout, now State geologist of Ohio, who, some 40 years ago, conducted me to localities near Sciotoville, and to whom I owe much of my best material from that region. Nor should I fail to remember another old and valued friend, Thomas Piwonka, of Cleveland, Ohio, a keen amateur geologist and an enthusiastic collector. He assisted in making many of my collections from Ohio and Pennsylvania and freely donated specimens from his own.

\section{SYSTEMATIC DESCRIPTIONS Genus LINGULA Bruguière}

Lingula arcta Girty, n. sp.

Plate 9, figures 1-4

Shell of medium size, or less; width and length varying but little from a ratio of $1: 2$. Outline elongatesubelliptical. Sides almost straight or very slightly arched and almost parallel, rounding together above and below, so that the anterior end is somewhat truncated and the posterior end takes the form of a blunt point. The pedicle valve was probably more pointed than the brachial valve, but if both valves are present among my specimens they have not been definitely distinguished. What appears to be the brachial valve shows upon exfoliation a well-defined muscular area of 
large size though distinctly less than one-half the total length; it has the usual cordate shape and a finely, strongly, more or less regularly corrugated surface.

The sculpture consists of very fine, sharp concentric striae, some of which at rather remote and regular intervals are stronger than the rest, marking stages of growth.

This species has been recognized at several more or less widely separated localities representing possibly several different horizons. It seems to be rather abundant in the Chagrin shale of northeastern Ohio. Figure 1 represents a slab containing one complete specimen and parts of three others, all single valves and all exfoliated. Figure 2 represents a fifth specimen, also from the Chagrin shale; it is larger than the others but appears to belong to the same species. Though it has been deformed by pressure, it is included among the types because of its well-preserved sculpture. Another specimen (fig. 3) was collected at Union City, Erie County, Pa., at what may be essentially the same horizon as the types. It occurs in a fine sandstone and is exfoliated. It is somewhat larger and somewhat more elongate than the specimens from the Chagrin shale, but the differences are hardly sufficient to warrant a distinction. Another specimen (fig. 4) was collected near Warren, Pa., at a horizon which has not been determined with reference to the others. Its specific relations are also less definite, for it is imperfect at the posterior end, but if not the same species it is clearly a related one. This specimen also occurs in a matrix of fine sandstone and is exfoliated. Mention should also be made of a specimen figured by Hall and Clarke (pl. 9, fig. 18) under the designation Lingula sp. ? cf. L. cuyahoga. It is cited as from the Chemung formation at Panama, $\mathrm{N}$. Y., but the term "Chemung" here must be taken in the broad sense. In size and proportions this specimen is closely comparable to the one from Union City represented by my figure 3 .

The specimen from New York and consequently authentic $L$. arcta do appear to resemble $L$. cuyahoga, as is indicated by the formula under which the specimen figured by Hall and Clarke is cited, but there is some doubt as to how $L$. cuyahoga should be interpreted. Hall described the species as having the length and width in the proportions of $5: 3$, thus indicating a much broader shell than his figure and one that is decidedly broader than L. arcta. Lingulas are abundant at Cuyahoga Falls and Akron, the localities from which $L$. cuyahoga is cited, and I have numerous specimens but none that is comparable to Hall's figure; Herrick, however, figures a specimen of similar proportions. From this same general locality and horizon Herrick cites $L$. atra, n. sp., and L. meeki, n. sp., besides L. cuyahoga as above. L. cuyahoga as described by Hall (though not as figured) would appear to be similar to L. atra. My specimens from Cuyahoga Falls vary appreciably in shape, some being comparable to $L$. atra, others to $L$. paracletus
Hall and Clarke, which should also be brcight into this galaxy. Lingulas of similar character are also abundant in northwestern Pennsylvania in tha Orangeville shale member of the Cuyahoga formation and some of the higher formations, and it will $b$ difficult to apportion them among the species recognized in the Ohio $†$ Waverly. Indeed, it would seem doubtful if there could be so many as six valid species of Lingula in the same region at horizons which come within a somewhat narrow range. I refer to L. atra, L. cuyahoga, L. gannensis, L. melie, L. paracletus, and L. membranacea, all cited from the †Waverly group of Ohio. From all these species, not even excepting $L$. cuyahoga, $L$. arcta is clearly distinct. It is more elongate than either Hall's figure or Herrick's, and to any intrinsic difference the difference in horizon and faunal association would give added significance. There can be no question whatever if $L$. cuyahoga has the proportion? ascribed to it in Hall's description; in that case $L$. cuyahoga would apparently resemble $L$. gannensis or some one of the other related forms.

A species very similar to $L$. arcta occurs in th 9 Bedford shale, L. herrickana of these notes. The differences shown are not marked and may not be con ${ }^{\circ}$ ant, the fact being at present impossible to determine, as both species are rare. The circumstance that the faunas of the Chagrin and Bedford are so different as a whole casts a shadow over the probability that even the same species of Lingula occurs in both.

L. louisianensis, a species at present know'n only in the Mississippi Valley, is somewhat comparable to L. arcta. If found together they might be hard to distinguish, though $L$. arcta is the more slender form. The wide geographic separation between the localities at which these species are known and the great unlikeness in the faunas associated with them make it unwise in this case also to assume that the proper differences, however slight, are without importance.

Horizon and locality: Chagrin shale; Bedford, Ohio (station 3554), Brecksville, Ohio (station 3555); and an urdetermined horizon below the Knapp formation (†sub-Olean cor slomerate), $1 \frac{1}{2}$ miles northeast of Warren, $\mathrm{Pa}$.

\section{Lingula eriensis Girty, n. sp.}

Plate 9, figures 5-9

Shell of medium size, rather regularly ovate in outline, though somewhat truncated in front. Length $1 \frac{1}{4}$ to $1 \frac{1}{2}$ times the width. Convexity very low.

The test is thin, and the inner layers, at least, are highly phosphatic and lustrous. Inconclusive observations suggest that the exterior may have be?n dull or finely roughened. External molds show that the outer layer was nearly smooth, marked only by very fine, somewhat irregular incremental lines, which tend to become fasciculate over the marginal parts, especially toward the posterior end. On the interior th s cordate 
visceral area is rather distinctly shown by curved transverse striae.

The pedicle valve is scarcely distinguishable from the brachial valve in shape. It is somewhat more pointed at the posterior end, but some specimens cannot be satisfactorily identified by that means.

L. eriensis is closely related to a species found in the Bedford shale, from which it may be distinguished by its more oval shape, for it contracts more strongly above and has a proportionally greater width. It also resembles $L$. ligea of the Hamilton group, but it is less elongate. In the tWaverly group it resembles L. meeki. That species, however, besides occurring considerably later in geologic time, appears to be more distinctly striated than the nearly smooth $L$. eriensis, for the surface is described as being "marked with the usual concentric striae." In the early Carboniferous faunas of the Mississippi Valley no species closely comparable to this has been described.

So far as known, $L$. eriensis is restricted to the Chagrin shale, and it is found there in considerable abundance, though mostly at localities where other fossils are rare. The two valves are likely to occur together and to lie obliquely to the bedding, both circumstances carrying a suggestion that these shells were buried where they lived and at most were not transported far.

$L$. eriensis occurs in association with $L$. arcta, but the species are quite distinct, not only in shape but also, apparently, in their surface markings. Those of $L$. arcta are well shown and consist of exceedingly fine but sharp and regular growth lines. Nothing comparable to this is shown by my specimens of L.eriensis, in which the concentric lines are much coarser, much farther apart, and much less regular in size and spacing.

Figure 5 represents a specimen from McKean County, Pa., referred to the species only provisionally. It is apparently a dorsal valve preserved as a mold in sandstone, and it has been somewhat distorted by lateral compression. It does not differ markedly from figure 6 , and the difference may, in part at least, be due to distortion.

Horizon and locality: Chagrin shale, Paines Creek (station 3552), Big Brook, Orange Township, Cuyahoga County (station 3553), Brecksville (station 3555), Bedford (station 3556), all in Ohio. 70 feet below the Olean conglomerate member of the Pottsville formation, Bingham, Pa. (station 3492).

\section{Lingula papyracea Girty, n. sp.}

\section{Plate 9, figures 15-18}

Shell rather large, spatulate. Length about $1 \frac{1}{2}$ to $1 \% 3$ times the greatest width. Sides gently convex; more strongly curved above and below, contracting somewhat toward the posterior extremity. Extremities rounded, the anterior extremity more broadly than the posterior. Specimens vary in the posterior outline; those which are more bluntly rounded are presumably dorsal valves. The shell substance is thin, and tha valves are almost flat. These characters may be dus to maceration and compression, but it should be borno, in mind that Trigonoglossa irvinensis in the sam9 beds has not been similarly affected. That species has a stout shell, and its convexity appears to b? normal.

The surface is almost smooth except for what appear to be fascicles of growth lines, though the growth lines themselves are exceedingly faint. The fascicles on low ridges are spaced at rather regular and close intervals; they are consequently numerous and on some specimens rather conspicuous. This may read as if the surface markings were similar to those of Trigonoglossa irvinensis, but there is no real resemblancis between the species.

More species of Lingula have been described from or identified in the + Waverly rocks of Ohio than can be readily distinguished. Specimens from the same lo. cality often show material differences in shape, and though some of these differences may by surmise be ascribed to their function as dorsal and ventral valves, the real nature of the valves can rarely be established, and some of the differences cannot be so attributed. If it is granted, as I believe it must be, that the difference in shape between the valves of the same individual is sometimes as great as the difference in shape upon which certain species have been founded, it would seem that in this genus more than in many another emphasis should be laid upon regional and faunal differences, unless, of course, pronounced intrinsic differences render such emphasis superfluous.

Lingula papyracea, by individual specimens, resembles several Waverly species. One of these is $L$. paracletus Hall and Clarke, which was described from the Cuyahoga shale at Chardon, Ohio. As linguloid shells of similar character are very abundant in the Orangeville shale member of the Cuyahoga, it may be inferred that $L$. paracletus came from that horizon. Specimens from that unit, as at Orangeville, have much the shape of $L$. paracletus, but they ar? materially smaller. The holotype of $L$. paracletus has a length of 16 millimeters, and the figure given by $\mathrm{HaIl}$ and Clarke is enlarged 3 diameters. Specimens from the Orangeville shale member which have a length of 10 millimeters are exceptional. Aside from a differences in horizon and faunal association, I am not able to name any signal difference between $L$. papyracea and $L$. paracletus if certain specimens only are taken into consideration. L. papyracea, it may be inferred, is a some what larger species, and it has a thinner shell, for $L$. paracletus retains distinct muscular imprints, which it could hardly do if the shell were not rather massive; and it is said to have notably broad margins of contact, though this expression may mean that the valves aro rather convex but shelve outward at the sides. No specimens that could be referred to $L$. paracletus witl 
complete assurance, however, are available for comparisons.

Some specimens of $L$. papyracea resemble L. cuyahoga; they are not so slender as Hall's figure but are more slender than is indicated in his description. I do not recall a single specimen from the general locality and horizon which furnished the type specimens of $L$. cuyahoga that has the slender shape of Hall's figure, though Herrick and Meek have figured specimens having similar proportions. My specimens from the same horizon have more the proportions specified in Hall's description and resemble Herrick's L. atra. Meek's specimen, which came from Harts Grove, in Ashtabula County, was identified as $L$. membranacea Winchell. It not only resembles Hall's figure of $L$. cuyahoga but is even more similar to Herrick's figure of L. gannensis. If by any chance Meek's specimen actually belongs to L. membranacea and if Hall's figure gives the actual proportions of $L$. cuyahoga, it would be difficult indeed to find any specific distinctions, from the figures at least. It might also be difficult to determine which name has priority, as both were published in 1863. L. membranacea was described from the Kinderhook group at Burlington, and Winchell also cites it from the late Devonian or early Carboniferous rocks at Shafers, Pa., but no one knows what sort of a shell he had. His specimens from Shafers were apparently contained in the Andrews collection, which cannot now be located. Authentic L. membranacea does not concern this discussion. Winchell himself did not figure the species, but Weller gives a figure of the holotype. The specimen is imperfect and the species hardly recognizable. Weller says that specimens from the †Waverly which have been identified with $L$. membranacea by Winchell, Meek, and Herrick are all specifically different. Just how the statement could be substantiated with regard to Winchell's identification at Shafers it is hard to see; nevertheless it is probably true.

Of the species of Lingula known from the typical Mississippian faunas, $L$. papyracea resembles $L$. varsoviensis and $L$. indianensis, especially the former, but it would be unprofitable to pursue this subject further.

$L$. papyracea requires no comparison with its associates in the Bedford shale. It is, however, more or less closely related to $L$. eriensis of the Chagrin shale. The differences are not great, but as at present known $L$. eriensis is smaller, more elongate, less pointed at the posterior end, and nearly smooth, or at least not so distinctly marked by fasciculate growth lines.

This discussion should not terminate without mention of a peculiar feature shown by one of the specimens (figs. 12 and 12a), apparently a dorsal valve. In this specimen some of the later additions to the shell are carried completely around the posterior end, so that the beak, which had the normally terminal position at a stage just antecedent, has it no longer. The form of construction is in a measure comparable to that of the dorsal valve of Orbiculoidea, except that the beak, or apex, in Orbiculoidea was at no stage terminal. It is not clear how this singular feature could have been produced accidentally by a flattening out of the shell at the posterior end; it certainly is not due to the projection there of the complementary valve, and it seems to be a pathologic or else an old-age character.

$L$. papyracea is rather abundant in the Bedford shale of northern Ohio but is not yet known from that formation either in central Ohio or in Kentucky.

Horizon and locality: Bedford shale, Bedford (station 721), Blue Rock Springs (station 952), and Euclid (stat:on 953), all in Ohio.

\section{Lingula limatula Girty, n. sp.}

Plate 9, figures 10-12

Shell of medium size. Length about $1 \frac{1}{2}$ times the greatest width. Outline subelliptical, tending to pentagonal, with subparallel faintly arched sides and with the front regularly rounded or somewhat truncated. Posterior end in the ventral valve rather abruptly terminated by the two arched cardinal slopes, which meet in a very obtuse angle; in the dorsal valve this outline is a low regular curve. Convexity slight longitudinally, stronger transversely.

Surface marked by weak concentric undulations due to irregularities of growth and roughened by innumerable minute papillae of uniform size and distribution. The papillae are almost in contact and in places are confluent, forming short raised lines with ragged or papillose crests, which are in a general way ccnformable to the growth lines but are wavy and more or less inosculating. The shell is thick and where exfoliated appears to be regularly and rather coarsely punctate, but where exfoliated surfaces and external surfaces can be seen in juxtaposition it becomes clear that the "punctae" are but an expression of the papillae on the inner layers of the shell. They are really raised points w] ich correspond individually with the papillae of the exterior but are smaller and consequently farther apart. They are readily seen where exfoliation is slight but bocome less distinct as it goes deeper and on the inmost layers are very faint if not absent altogether. The shell does not seem to be punctate, therefore, in the same way that the terebratuloid shell is punctate.

This species belongs, by reason of its punctate shell, in the genus Lingulipora, but I have come to doubt whether punctate shell structure has the same significance in the Lingulas that it has in some other brachiopods-and consequently to doubt the utility of Lingulipora as a generic name. Indeed, punctate shell structure is not invariably given generic significence; some species of Syringothyris, for instance, are highly punctate, but others are essentially or entirely impunctate.

In shape $L$. limatula resembles several species of Lingula, some in the Devonian, others in the †Waverly, 
but the character of the surface is distinctive, and also the strongly "punctate" structure of the shell, if they are not the same thing. The species first called to mind in this connection is L. punctata of the Hamilton. The sculpture of $L$. punctata, however, on close examination proves to be altogether different from that of L. limatula, and the shell, judged from the few specimens I have examined, is not "punctate." L. limatula somewhat resembles $L$. randalli of this report, but the surface ornament is entirely different; the ornament of this species is essentially papillose, that of $L$. randalli purely lirate. In shape it closely resembles the $\dagger$ Waverly species $L$. atra, but here again the surface characters are wholly different.

The collection contains five more or less fragmentary specimens on two small slabs accompanied by a label reading "Venango group, Union City, Pa." Two of these are here figured (figs. 13 and 14). It also contains several specimens from the Chagrin shale which belong to the same or to a closely related species. The one figured, which is a dorsal valve, is a larger and somewhat broader shell, but it has a similar quadrate shape and a similar punctate or papillose surface. It is this specimen that gave warrant for noting the difference in shape between the dorsal and the ventral valve. It occurs on a small slab which also shows the posterior end of a ventral valve belonging evidently to the same individual.

Horizon and locality: An undetermined horizon in cliffs $4 \frac{1}{2}$ miles northwest of Union City, Pa.; and more or less doubtfully from the Chagrin shale at Bedford (station 3556) and Brecksville (station 3555), Ohio.

\section{Lingula herrickana Girty, n. sp.}

Plate 9, figures 13-14

Shell rather small, elongate, subelliptical. Length twice the width or a little less. Sides very gently convex in the median part, more strongly curved above and below. Anterior end strongly rounded; posterior end of nearly the same shape as the anterior but slightly more pointed, probably, in the ventral valve. Surface marked by very fine but sharp, somewhat wavy inosculating lirae.

Lingula herrickana is especially close to L. arcta of this report. The difference in shape, however, is regarded as sufficient to dintinguish them, and this difference, though not great, is given added weight by a difference in geologic occurrence and faunal association. Of species from the same faunal province already in the literature, $L$. herrickana will probably first call to mind L. melie, though much depends upon whose representation of the different tWaverly species is used. The authoritative figures are of course of prime importance. L. melie is very abundant at Chagrin Falls, Ohio, the locality that furnished the types, and specimens from that locality show rather wide variation. Many of them, and these perhaps represent the more common form, are broader than $L$. herrickana and more bluntly rounded across the anterior end. Specimens can be selected, however, that do not differ materially. The concentric striation also appears to be a little coarser in $L$. melie, though this difference is doubtfully constant and is not likely to be useful in distinguishing the two species. L. herrickana differs from Hall's original figures of $L$. melie in much the same way as it does from these specimens. Herrick figures as L. melie ${ }^{2}$ a specimen which came from the same locality and horizon as mine and which as restored might belong to the same species. This specimen apparently is the only Lingula that he found at Central College and is rather fragmentary. On the other hand, I found two species at Central College which are very unlike, and as $T$. irvinensis is abundant and $L$. herrickana rare, the probabilities are that Herrick's specimen belongs to $T$. irvinensis and that it is incorrectly restored: Even with the shape given it in Herrick's figure it might be a very slender specimen of $T$. irvinensis.

A knowledge of the surface markings of Herrick's specimen would resolve all doubts, for in that character $L$. herrickana and $T$. irvinensis are far apart.

Comparisons with L. cuyahoga are hardly called for, even if the species is interpreted on the basis of Hall's figure, still less if it is interpreted on the basis of his description, which indicates a broader shell. Herrick's figure of $L$. cuyahoga, however, rather closely resembles L. herrickana: so does Meek's figure of $L$. melie from Johnson, Trumbull County, Ohio, and Herrick's figure of $L$. membranacea from Loudonville, Ohio. So far as shape is a factor, all three specimens, from the figures, might readily belong to the same species.

It hardly seems profitable, either, to carry these comparisons over into the Mississippi Valley, for, if the faunas generally are a criterion, that region forms a faunal province distinct from that to which Ohio belongs. If found in the same faunal province $L$. herrickana might be difficult to distinguish from $L$. gorbyi or L. louisianensis.

In one of the cotypes (fig. 17) the sides contract slightly toward the front, but this is probably accidental. In other specimens, though they are but few and all more or less imperfect, the sides appear to be nearly parallel.

At present this species is known only from the Bedford shale of central Ohio, where it is somewhat rare.

Horizon and locality: Bedford shale, Central College, Ohio (stations 726, 726a).

\section{Lingula randalli Girty, n. sp. \\ Plate 9, figures 19-24}

Lingula randalli is an unusually robust species, which shows marked variation in shape and in proportions. Some of the variation can be seen from the

2 Herrick, C. L., Denison Univ., Sci. Lab., Bull., vol. 4, pl. 9, fig. 1, 1888. 
specimens figured. In these the length ranges from about 1.7 to almost 2 times the width, and the shape from subelliptical to subovate. The anterior end is strongly rounded, the posterior end pointed in some specimens, bluntly subangular in others. It seems probable that the pointed specimens are ventral valves; as such they would also be a little more elongate than the dorsal valve. Specimens that are especially blunt at the posterior end are presumably dorsal valves; some, however, have neither one shape nor the other and might be somewhat pointed dorsal valves or somewhat obtuse ventral valves. The shell is thick, as becomes a species of so large size, and the surface is marked by very fine but also very sharp raised lines, which in a general way conform to the outlines of the shell but are more or less wavy and inosculating.

Thus the narrow pointed specimen (fig. 20) is supposed to be a ventral valve; it has been laterally compressed, though not greatly, and it is consequently narrower and more convex than it was originally. The broad specimen (fig. 19) is supposed to be a dorsal valve; it apparently retains its original shape and convexity. The specimens represented by figures 21 and 22 are somewhat intermediate in shape; the original of figure 21 has been somewhat compressed laterally. All these specimens occur at essentially the same locality and the differences in shape and proportions, though certainly pronounced, hardly denote even varietal differentiation, at least of an effective sort.

I can hardly doubt that it was this species which Caster wished to identify as Lingula delia Hall, and possibly that identification may prove to be correct. On the data furnished by the original description and by the figure of the holotype, however, it is at least doubtful. I may note in passing that Caster's figure purports to be a copy of one given by Hall and Clarke in their brachiopod monograph. Hall and Clarke's figure is an enlargement to 2 diameters of the holotype, which was originally figured by $\mathrm{Hall}$ in the natural size. Caster's figure, however, has been greatly reduced from Hall and Clarke's, so that it is at the same time much smaller than the latter and much larger than the specimen itself.

The reasons for doubting that the form here described as $L$. randalli is identical with $L$. delia are these: $L$. randalli has a thick shell, whereas that of $L$. delia is said to be thin; the holotype of $L$. delia appears to be a dorsal valve and is twice as long as it is wide; $L$. randalli regularly (almost, if not quite) is a broader shell. Of the specimens of $L$. randalli chosen for types the only one that has essentially the same proportions as the holotype of $L$. delia is the original of figure 20 , but that specimen is a ventral valve instead of a dorsal valve, and at the same time it appears to owe its narrow shape, in part at least, to compression. If the holotype of $L$. delia is a dorsal valve, the corresponding ventral valve would be still more elongated; if it is a ventral valve it has a different shape from the ventral valve of $L$. randalli, at least from the specimen that has most nearly the same proportions. The two species may also differ in sculpture, but I. have no immediate way of arriving at the facts. On the other hand, the median septum which is regarded by Hall as a distinctive character of $L$. delia is present also in $L$. randalli (fig. 20), though a certain amount of thickening along the median line is not uncommon in fossil Lingulas. To the distinctions just mentioned may be added the fact that $L$. randalli is a much larger species than $L$. delia and occurs at a much higher horizon, but the intrinsic differences may disappear if comparisons are given a wider range and nct confined on the part of $L$. delia to the holotype.

$L$. randalli also more or less resembles certain species from the †Waverly group of Ohio, especially a form which Herrick figured under the title L. membranacea (he gives the horizon as above conglomerate II). Herrick's form, it should be noted, is entirel' different from the one which Meek called L. membranacea from Ashtabula County, to judge by the figures.

In the Mississippi Valley L. gorbyi (as figured by Weller) has much the same shape as $L$. randalli, but it is so much smaller (only about half the size) and in every adventitious character so different, that detailed comparisons would serve no good purpose. Nevertheless, through the courtesy of the University of Chicago. I have been able to examine two excellent sf ecimens of $L$. gorbyi, and from them $L$. randalli differs not only in its larger size but in having concentric lirae that are at the same time somewhat finer and much more flexuous and inosculating. The shape of $L$. randalli shows such variation that a general comparison in that category leads to no determined relation. Some specimens agree with $L$. gorbyi rather closely, and others disagree as widely, but all are very much larger.

I at one time identified $L$. randalli at a number of localities near Warren and also at Union City, Connellsville, and Tidioute, Pa., but as it has rot seemed profitable to verify these identifications, it is here definitely cited from only the two localities that furnished the types.

Horizon and locality: An unidentified horizon, 1/2 miles south of Warren, Pa., and 4 miles southeast of Warren, Pa. (cliffs of Brown Run).

\section{Lingula ligea Hall? \\ Plate 9, figures 25-29}

1867. Lingula ligea Hall, New York Geol. Survey, Paleontology, vol. 4 , p. 7 , pl. 1, figs. $2 \mathrm{a}, 2 \mathrm{~b}$.

1930. Lingula ligea. Caster, Bull. Am. Paleontolngy, vol. 15, no. 58 , p. 147 , pl. 31 , figs. 14,16 (p. 5 , pl. 10 of no. 58 ).

I have identified this species at several localities, at some of which it is very abundant. All tle localities are in the vicinity of Warren; Pa., and all but a few represent the horizon described on the labsl as upper Chemung where the phyllopod Crustacea r'ere found. 
The shells identified appear to have been thin and fragile, and most of them are more or less deformed by pressure. On this account their true shape and proportions are, up to a certain point, a matter of inference. As a further consequence a close discrimination of species, which even with the best of specimens is difficult, has here not been possible. The species has therefore been given a rather wide range in the characters ascribed to it, and consideration may well be centered on the specimens selected for illustration, which are among the best of those examined. With regard to these, I make note that the original of figure 29 , which appears to be a pedicle valve, is highly arched transversely, and its natural width has been reduced by lateral pressure. The same is true of the specimen represented by figure 25, which appears to be a brachial valve. The original of figure 26 is believed to retain its original shape and proportions; its dimensions are approximately, width 4.5 millimeters, length 8 millimeters. The original of figure 28 also appears to hold its shape unchanged; its dimensions are, width 4.5 millimeters, length 8.5 millimeters. Both of these specimens are thought to be ventral valves. The original of figure 27 , which appears to be a dorsal valve, has a width of 4.5 millimeters and a length of 8 millimeters, but the length has been diminished by pressure.

The specimens figured, which are fairly representative, are mostly smaller than those figured by Hall and a little more slender. One or two, except for size, are closely comparable to his figure $2 \mathrm{~b}$, which in turn is almost exactly like his figure 1 , an enlarged representation of a specimen of $L$. spatulata. The specimens from Warren, therefore, might almost as well be identified with $L$. spatulata as with $L$. ligea.

Caster cites $L$. ligea from the late Devonian or early Carboniferous rocks of Pennsylvania, but apparently only as "reported by Carll and Randall from the Chemung group at Warren, Pa." Caster also gives what purport to be reproductions of Hall's original figures, but the reproductions are so much larger than the originals and so inaccurate as to shape that one would hardly suspect that lineage. Note should be made that Caster's figure 15 is ascribed to Lingula cuyahoga in the text but to L. ligea in the description of plate 31 . I believe that the plate description is correct, that figures 14 and 16 were intended to reproduce Hall's figures $2 \mathrm{a}$ and $2 \mathrm{~b}$ of plate 1 (Lingula ligea) while figure 15 was intended to reproduce Hall's figure 8 of plate 2 (Lingula ligea var.). Note should also be made of a dual numbering both of the pages and the plates, one set for Caster's report (no. 58), and another for the volume as a whole (vol. 15). I am using the latter.

It seems to me somewhat improbable that the same species survived from Hamilton time, in which $L$. ligea lived, to that in which the present species flourished; much rather, in consideration of our limited means of distinguishing species in the genus Lingula, the two forms are actually distinct but yet indistinguishable ty the means at hand.

Comparisons with $L$. melie are in point more ty reason of the great range in shape allowed to the species as shown by Hall's two figures than by any real agresment of the specimens from Warren with specimens from Chagrin Falls, where L. melie occurs in abundanc?, yet my figure 26 is closely comparable to Hall's figure 3 . On the average $L$. melie seems to be a broader shell than the one here referred to $L$. ligea.

I am in no position to examine critically the sy:onymy of $L$. ligea given by Schuchert or to bring it up to date. Only Hall's description and Caster's recent publication are therefore cited as being mainly to ts? point.

This species appears to occur at numerous localities near Warren but always at the same horizon. It has not been expedient to corroborate these identifications, which were made many years ago, and the only locality mentioned specifically is the one that furnished tle figured specimens.

Horizon and locality: Phyllocarid horizon, hill at west end of Warren, Pa.

\section{Genus TRIGONOGLOSSA Dunbar and Condra}

1932. Trigonoglossa Dunbar and Condra, Nebraska Geol. Survey Bull. 5, 2d ser., p. 35.

There seems at first no basis for disagreement with Dunbar and Condra in their proposal of the new genus Trigonoglossa to receive certain linguloid shells that have of late rather generally been referred under Glossina, but if one looks into the matter it becomes more involved. These authors have explained how Hall and Clarke revived Phillips' term "Glossina" ard how Cockerell replaced "Glossina" with Paleoglosix (which they at first misprint "Paleoglossina") upon tl a certain grounds that it was a homonym of Glossirn Wiedmann. The genotype of Paleoglossa obviously holds over as that of Glossina Phillips, and all must agree that the genotype of Glossina Phillips is his species Lingula attenuata.

The passage in which Phillips introduces the term "Glossina" is quoted by Dunbar and Condra and need not be repeated here. The points that seem to $h$ ? significant are that Phillips mentioned two species, $L$. attenuata and $L$. crumena, and that neither of them is specified as the typical one. The distinction b?tween "Glossina" and Lingula was made to rest upon whether the shell of "Glossina" was equivalve or inequivalve, and Phillips said that he had been able to establish the facts only with regard to Lingula attenuata. L. attenuata on that account undoubtedly must be taken as the type species of "Glossina." Apparently Phillips was under the impression that Lingula was equivalve, and he sought to distinguish "Glossina" on the grounds 
that it was not. As a matter of fact, all or nearly all species of Lingula are also inequivalve, and the Glossina of Phillips or the Paleoglossa of Cockerell must rest for its validity on other grounds.

It would seem as if Hall and Clarke, in reviving Phillips' term Glossina, rested its distinction from Lingula upon its supposedly triangular shape, for they speak of "the group of subtrigonal forms constituting Glossina," and this interpretation has been rather widely followed by authors, including Schuchert in his brachiopod bibliography. Now L. crumena, which is admirably figured in the work in which the genus "Glossina" is proposed, is a typical example of "Glossina" as interpreted by Hall and Clarke. It is a large, elongate, cuneate shell which, however, varies considerably in shape and proportions. Lingula attenuata, on the other hand, which was the only other species mentioned under "Glossina" but was not figured at the time, does not come satisfactorily under Hall and Clarke's interpretation of the genus, although it is unquestionably the genotype; it is a small species and rather on the ovate order as to shape. From these facts one would be led to believe that Hall and Clarke's conception of "Glossina" was based upon $L$. crumena instead of $L$. attenuata-upon the species that was figured instead of the one that was not. However, if shape is made the controlling feature of "Glossina," as that genus was interpreted by most authors up to the time of Dunbar and Condra, it is not hard to see how L. attenuata, L. crumena, and many other species could reasonably be included under it, for by an increased arching of the three sides, the subtrigonal outline passes by degrees into the subovate, and in fact among linguloid shells almost every gradation can be found between them. The distinction between "Glossina" of Hall and Clarke and Lingula would be quite arbitrary.

Hall and Clarke, when they revived "Glossina" as a subgenus of Lingula, referred to it specifically only three species- $L$. acuminata, from the $†$ Calciferous sandstone; $L$. riciniformis, from the Trenton limestone; and $L$. flabellula, n. sp., from the $\dagger$ Waverly group of Ohio. In shape L. acuminata and L. fabellula are somewhat intermediate between $L$. crumena and $L$. attenuata, for their lateral outlines are nearly straight, like those of $L$. crumena, instead of being gently arched, but their anterior outline instead of being gently arched is rather deeply bowed. L. riciniformis is more comparable to $L$. attenuata than the others, if it is interpreted as a ventral valve (as it has been), but if it is interpreted as a dorsal valve the ventral valve would probably have much the shape of $L$. acuminata and L. flabellula, a circumstance which illustrates the insecurity of classifying linguloid shells on small differences in shape, for the valves almost always occur separately, are somewhat rarely determinable as dorsal and ventral, and may differ from each other in the degree in which species themselves are distinguished.
Schuchert included under "Glossina" numerous species not mentioned by Hall and Clarke, but on the other hand he referred the Glossina acuminata of those authors to the genus Lingulepis and returned their Glossina riciniformis to Lingula s. s. Among the Glossinas of Schuchert are the four recorded species which Dunbar and Condra include in Trigonog'ossa.

Dunbar and Condra in proposing the genus Trigonoglossa say that it embraces "a group of Carl'nniferous species distinguished by their striking concentric ornamentation and broadly triangular form," and they wonder what originally led to the assignment of "these late Paleozoic species to that Ordoviciar genus," meaning the genus Glossina of Phillips. These late Paleozoic species are, exclusive of $T$. kentuckyensis, which they describe as new, Lingula sedaliensis Miller, L. flabellula Hall and Clarke, L. waverlyensis Herrick, and $L$. nebraskensis Meek, the last being named as the genotype of Trigonoglossa.

The validity of Trigonoglossa as distinguished from "Glossina," or we should better say Paleoglossa, rests on the more or less exclusive possession of the characters ascribed to it, which are its shape and its sculpture. Though the application of terms is to some extent a matter of personal opinion, I should say that in shape some species of Trigonoglossa are not broad but elongate, and that some are not triangular but ovate. Thus the $\dagger$ Waverly species which Meek figured as Lingula scotica? and the species, also probably from the $\dagger$ Waverly, which Hall and Clarke figured as $L$. waverlyensis are decidedly elongate and do not differ materially (except in size) from one of the original figures of L. crumena, while in their proportions they essentially are as elongate as $L$. attenuata, though appreciably different in shape. T. kentuckyensis, on the otherhand, is broad, but because of its highly arcuate anterior margin it is hardly triangular. That species and the somewhat more slender T. flabellula are less triangular than ovate. Herrick's figure of $T$. waverly'onsis and Weller's figure of $T$. sedaliensis are closely comparable to one of the figures of $L$. crumena, while $L$. irvinensis (which is not mentioned by Dunbar and Condra but which has the distinctive sculpture of Trigonoglossa) is very similar in shape to Paleoglossa attenviata or to Lingula meeki Herrick, if that species is not in fact a Trigonoglossa. Thus, not to engage in more elaborate comparisons, there is nothing in the shape of Trigonoglossa that is distinctive except in a very general way. Fairly close parallels can also be found between Paleoglossa and Lingula so far as those groups are separable.

Trigonoglossa would seem to rest for its validity upon the combination of a subovate or subtrigonal shape with a coarsely striated surface, a combination in which the sculpture is much more significant than the shape. Dunbar and Condra seem to imply that Trigonoglossa differs from Paleoglossa (Glossina) in both items, and 
they describe $P$. attenuata as marked by fine lines of growth like those of Lingula. If it were not for this difference one would be put to it to name any substantial distinction between Trigonoglossa and Paleoglossa, for species of Trigonoglossa differ as much from one another in shape as some of them differ from $P$. attenuata. In fact, the two specimens of $T$. nebraskensis figured by Dunbar and Condra (not to mention the one figured by Meek) differ from each other almost as much in shape as either of them does from $P$. attenuata, for one figure has a broad, acuminate-ovate shape closely similar to that of $T$. kentuckyensis, and the other (though the original specimen is imperfect) has a narrow, cuneate shape similar to that of $L$. scotica? of Meek and $L$. waverlyensis of Hall and Clarke, above mentioned. The wide difference in geologic age between the two genotypes, however, should enhance the significance of such differences as are shown by them, although in point of shape similar or intergrading forms are found through the intervening periods.

Dunbar and Condra also seem to imply that Trigonoglossa is a Carboniferous genus, though that implication was probably not intended to be taken so literally. In my experience with Carboniferous and late Devonian Lingulas, the group of Trigonoglossa does seen to be sharply defined, chiefly by its sculpture, yet somewhat also by its shape. I have never observed any shells in which the subtriangular or acuminate-ovate shape of the more extreme examples of Trigonoglossa is combined with the fine striation of Lingula or any in which a subquadrate shape such as is found in Lingula is combined with the strong, spaced lirae distinctive of Trigonoglossa. However, so many species of Lingula are known only from exfoliated or macerated specimens that such combinations may occur, and Trigonoglossa may graduate into Lingula, s. l., as completely in its sculpture as it does in its shape. Thus the extent to which Trigonoglossa is restricted to faunas of Carboniferous age is uncertain, for many species that rest under Lingula are entirely acceptable under Trigonoglossa on the score of shape, while owing to their poor preservation their sculpture is not definitely known. The Hamilton species Lingula paliformis has in Hall's original figure a shape closely comparable to that of Trigonoglossa nebraskensis as figured by Meek, and the sculpture also seems not to be incongruous with Trigonoglossa, for it is said to consist of "strong concentric lamellose striae." Specimens subsequently figured by $\mathrm{Hall}$ and Clarke are extremely similar to T. flabellula in outline. It is true that Hall and Clarke refer L. paliformis under the genus Lingulella? The essential difference between Lingulella and Lingula seems to consist in the manner of exit of the pedicle, which in Lingula rests upon a groove and in Lingulella issues from a slit of similar size and shape. Hall and Clarke justly say that great caution must be exercised in determining the facts. Thus in $L$. paliformis we either have (1) a pre-Carboniferous species of
Trigonoglossa, (2) a species of Lingula which is intermediate in sculpture between the microscopic striation of that genus and the coarse strong striation of Trigonoglossa, or (3) a species which brings Trigonoglossa into close relationship with Lingulella so far as they can be distinguished at all readily.

Now if Trigonoglossa is given recognition mainly on the grounds of its sculpture, there are other species of Lingula that are perhaps equally worthy of generic separation on the same grounds. Hall and Clarke say "The surface ornamentation of Lingula is subject to but little variation, yet a few species are striking exceptions. In L. punctata of the Hamilton group, the fine surface lines are wrinkled into a sort of herringbone pattern." Several species (such as L. granulata Phillips and L. limatula Girty, n. sp., of this paper) have a granulose surface, and in L. lamellata the surface is covered by broad transverse imbricating lines that are discrepant to the lines of growth. Some species again appear almost smooth; others (like some of the Carboniferous forms) have extremely fine but also very sharp concentric striae. The circumstance that Lingulas are apt to occur in shale, especially black shale, and in a more or less macerated condition makes it difficult to determine the original sculpture, and descriptions that are accurate enough as to fact may be in essence misleading.

In conclusion, it would seem in the present state of our knowledge that (1) Paleoglossa (Glossina Phillips) is not adequately distinguished from Lingula as generally interpreted; (2) Trigonoglossa may in a general way be the same as "Glossina" of American authors, depenc'ing upon what sculpture the several species possessed, for shells that might reasonably be referred to Trigonoglossa on the strength of their shape are found at numerous horizons in the Paleozoic, and on that score both of the original species of "Glossina" could properly find place in Trigonoglossa (compare $P$. attenuata with $T$. irvinensis and P. crumena with T. scotica? of $\mathrm{Mee}^{\mathrm{l}}$ or T. waverlyensis of Hall and Clarke); (3) Trigonoglossa is distinct from Paleoglossa and from Lingula on sculpture alone, if the entire content of each generis: group is considered; (4) the status of a great body cf linguloid shells as between Lingula, Paleoglossa (if distinct from Lingula), Lingulepis, and Trigonoglossa is uncertain; and (5) several other genera of linguloid shells are open to distinction on a basis quite as sound as that of Trigonoglossa.

Trigonoglossa flabellula (Hall and Clarke) Dunbar and Condra

Plate 9, figures $42-45$

1892. Lingula (Glossina) flabellula Hall and Clarke, New Yor ${ }^{1-}$ Geol. Survey, Paleontology, vol. 8, pt. 1, p. 172, pl. 1, figs. 33, 34. Waverly group; Sciotoville, Ohio. Berea grit, Berea, Ohio.

1895. Lingula (Glossina) flabellula. Hall, New York Univ. 48th Ann. Rept., for 1894, vol. 2, p. 326, pl. 1, figs, 5, 6 . Waverly group, Sciotoville and Berea, Ohio. 
1897. Lingula (Glossina) flabellula. Hall, New York State Geologist, 14th Ann. Rept., p. 326, pl. 1, figs. 5, 6 . Waverly group, Sciotoville, and Berea, Ohio.

1932. Trigonoglossa flabellula. Dunbar and Condra, Nebraska Geol. Survey, 2d ser., Bul. 5, p. 35.

Large cuneate Lingulas such as until recently have been referred under the genus Glossina are known from several localities and horizons in the Carboniferous rocks of Ohio. The relations of these forms to one another have been as variously interpreted as there were various writers, so that at present it is difficult to find any solid ground in the entire subject, the natural difficulties being enhanced by statements hard to verify. Said briefly, these shells have been cited from the tWaverly group of northern, central, and southern Ohio and from the Pottsville of central Ohio. Another citation from the †Waverly of Pennsylvania close to the Ohio border likewise concerns us.

The first notice of these shells was published by Meek. It was based upon a single specimen which he thought was probably the impression of a pedicle valve and which he identified, though with considerable doubt, as the English species Lingula scotica. In Weller's bibliography Meek is quoted as citing this species from the Berea sandstone at Berea, Ohio, but the warrant for this is not known to me. Meek himself is much less explicit, for he gives merely "Waverly group, Ohio," so that from the published information his specimen might have come from any horizon in the tWaverly or from any part of the State. The Berea sandstone is almost unfossiliferous (I have seen a few poor fossils from the Berea but have never succeeded in finding any) and for that reason the horizon imputed to Meek's citation appears to me less probable than almost any other.

In Schuchert's bibliography of North American fossil brachiopods the Lingula scotica? of Meek is placed in the synonymy of Glossina waverlyensis and the distribution of $G$. waverlyensis is given as Berea and Newark, Ohio, and Oil City, Pa. By a process of exclusion (Herrick being responsible for Newark, and Hall and Clarke for Oil City) Weller may have concluded that the residual citation of Meek (Lingula scotica?) went with the residual locality (the Berea sandstone at Berea), but Schuchert not uncommonly amplified the distribution and range of species, as they appeared in literature, by material in his brachiopod collection; such appears to be the fact in the case of Glossina waverlyensis. If so, it means merely that a form believed to be the same species as Meek's Lingula scotica? is believed to occur at Berea. The horizon is not necessarily the Berea sandstone, nor, if so, does it in any material way affect the dubiety that surrounds the horizon of Meek's specimen, the original Lingula scotica?. In this connection I may note a slight error or inconsistency in Schuchert's recording of these citations. He records Glossina flabellula as present only at Sciotoville, although Hall and Clarke both cite and figure the species from Sciotoville and from the Berea sandstone at Berea. Nor in that record does he omit their figure of the specimen from Berea. As Schuchert thus leaves out under G. flabellula an occurrence of Glossina at Berea that is recorded in the literature, and includes under $G$. waverlyensis an occurrence of Glossina at Berea that is not recorded in the literature, one might guess that he intended to divide G. flabellula as described and place the Berea specimen in $G$. waverlyensis, but this is hardly to be believed. Much more probably we are dealing with an accidental omission. Another statement regarding this specimen of Meek's is hard to justify from facts currently known. Miss Morningstar, clso a conscientious writer, says that Meek's figure of "Lingula scotica?" was a restoration based upon "very fragmentary remains." The original of Meek's figure may be extant, and Miss Morningstar may have seen it, but she does not say so. Meek states that his specimen (he had but one) was a cast, but he does not imply that it was incomplete or otherwise imperfect. I susnect that Miss Morningstar was thinking of Herrick's specimen instead of Meek's.

The next one after Meek to describe a shell of this character from the Carboniferous rocks of Ohio was Herrick, in 1887. Herrick's specimen (he also had but one, and it was very fragmentary) came from the lower Mercer limestone in Flint Ridge. Herrick cites this Pottsville form as Lingula scotica (var.?) and says that "if Meek's figure is accurate the Waverly snecies has quite a different outline from the Scottish" and that "it is probable, judging from the fragment. that our specimen had nearly the form of the European." In contradiction to this, he also says that his specimen agrees "pretty closely" with Meek's form, and his restoration of the Pottsville shell, which consisted of but the lower half of the valve, is in such exact agreement with Meek's figure of the †Waverly specimen that it might be a tracing even if it was not.

The following year (1888) Herrick, having found some shells of this type in the higher $† W^{\top}$ averly at Newark, says specifically that there are two or more forms related to $L$. scotica in our American rocks and that the + Waverly and Pennsylvanian forms need to be distinguished. Pursuant to this opinion and to the one expressed the year previous, he introduced the name Lingula waverlyensis for the Mississippian species, figuring two specimens from Newark. Some years later he republished the original figures of $L$. vaverlyensis without any text under the singular formula Lingula (scotica var.) waverlyensis.

To leave for the moment the †Waverly sholls, which are the real subject of this discussion, the general probabilities point to the conclusion that the Pottsville form will prove to be distinct from any tWaverly species and that it will also prove to be distinct from the British L. scotica; furthermore, it seems desirable that these relations should find expression in the names 
employed for the fossils. Nevertheless the Pottsville form came to be cited, and still is, under the designation Glossina waverlyensis. Under that designation Miss Mark in 1911 figured a specimen from the same general locality and horizon as Herrick's (Flint Ridge), and Miss Morningstar in 1922 figured, also as Glossina waverlyensis, a specimen from the same horizon but from the adjacent Muskingum County, though anticipating that this would eventually prove a distinct species. Miss Mark's figure was without text. Miss Mark's figure and Miss Morningstar's figure differ considerably, the former being more or less triangular in shape, the latter broader and more ovate. Miss Mark's figure, therefore, is more comparable to Meek's figure of "Lingula scotica?"; Miss Morningstar's to Herrick's figure of " $L$. waverlyensis". If this Pottsville form is in fact distinct from $L$. waverlyensis it seems to be without a name, unless it belongs under $L$. nebraskensis. It is almost certainly not $L$. kentuckyensis.

To return to the $†$ Waverly forms. L. waverlyensis as figured by Herrick is materially different in shape from "Lingula scotica" of Meek, and if there is any constancy of shape in these shells (which is a debatable point) they probably belong to different species. As is well known, all these forms come under the genus Glossina as interpreted by Hall and Clarke, and the transititon from "Glossina" to Paleoglossa and finally to Trigonoglossa is sketched in the preceding discussion of the genus Trigonoglossa.

Now when, as related above, Hall and Clarke revived the generic term Glossina, they both described a new species from the †Waverly rocks of Ohio, $G$. flabellula, and figured a specimen from Oil City, Pa., which they identified as $G$. waverlyensis. It is somewhat curious that the species from Ohio is described as Lingula flabellula but figured as Lingula (Glossina) flabellula, whereas the form from Oil City, which is just as good a Glossina as the other, is figured as Lingula waverlyensis. These authors do not compare G. flabcllula with any of the forms mentioned above, of which the most likely in point of occurrence is $G$. waverlyensis. $G$. flabellula does in fact show marked differences from $G$. waverlyensis as they identify it, but their $G$. waverlyensis not only was found at a much lower horizon and in a different State from the original, but in itself is smaller, narrower, and more triangular than typical waverlyensis; it very closely resembles, in shape at least, the Lingula scotica? of Meek. G. flabellula appears to me to be more closely comparable to true $G$. waverlyensis than the shell from Oil City, and if the latter can be referred to Herrick's species so, a fortiori, can $G$. flabellula, which consequently would become a synonym. Provisionally, I am regarding the form from Oil City as wrongly identified and $G$. flabellula as related to but distinct from $G$. waverlyensis.

Two specimens are figured to typify $G$. flabellula, one from Sciotoville, the other from the Berea sandstone at $47+45-39-3$
Berea. The two figures are very similar as regards shape, but as it may be desirable to restrict the species to one of them, I designate that from Sciotoville (fig. 33) as the holotype. It is obviously the better specimen, for it shows some sculptural features; the other specimen appears to be completely exfoliated.

The specimen of $T$. flabellula from the Berea sandstone is very similar in shape to the holotype from Sciotoville, the chief difference being that the anterior end is not quite so arcuate, a feature, however, in whick the figure of the holotype is said to be inaccurate. Now Hall and Clarke's specimen of T. fabellula and Meek's specimen of $T$. scotica? are reported as coming from the same locality and the same horizon, the Beres. sandstone at Berea, though I feel that the facts in botr instances need to be verified. That specimen of $T$. flabellula as figured differs materially from the specimen of $T$. scotica? , being much broader and having a some. what more deeply curved anterior outline. If shape is a reliable character, there would appear to be two distinguishable species of Trigonoglossa in the Berea sandstone or more likely one very variable species. Thero is much here that is very questionable, however.

The holotype of $T$. fabellula is said to come from Sciotoville, Ohio, and it was found, I make no doubt, at the well-known locality on the Ohio River-namely, the bar at the mouth of the Little Scioto. My collections from this locality contain a number of specimens of $T$. flabellula, which enable me to add to our knowledgo of the species.

In most of my specimens the shape is conspicuousl! triangular, with long, nearly straight sides and a long, gently convex anterior margin. The three sides ari connected by strong curves, the posterior end in fact being almost pointed. In Hall and Clarke's figure of the Sciotoville specimen the anterior outline is mor? deeply rounded than in most of mine, so that the shap? is ovate rather than triangular, but the drawing is said to be at fault in this regard. In one of my specimens. on the other hand, the ovate shape is suggested. Hall and Clarke's specimen, which appears to be above the a verage in size, is decidedly longer than it is wide (42 millimeters in length by 36 millimeters in width); in some of my specimens the two dimensions appear to be almost equal, but variation in these proportions is doubtless partly due to the long ones being pedicle valves and the short ones brachial valves, for thoug. the two valves have not been found in conjunction (at least in a condition to be measured), there is reason to believe that they differed materially in length and also in the shape of the posterior end, whether pointed or rounded. The convexity is rather strong for a species of Lingula: the transverse arch, though low and broad, is, near the sides, rather strongly turned dowr ward. Lengthwise the convexity is more even.

The most conspicuous surface markings consist of delicate raised lines spaced at rather regular and wide 
intervals, the width of each interval being many times that of the enclosing lirae. The surface between these lirae is essentially flat. On corresponding parts of different specimens the scale of these markings varies considerably so that a space of 5 millimeters may embrace from 8 to 11 lirae. On the same specimen, however, the spacing is almost constant, though the lirae are a little more closely arranged toward the posterior end. These markings, though fine, can be seen without a lens; in addition the surface is also crossed by fine incremental lines which may be fasciculate so as to produce minute concentric undulations, all on a microscopic scale. They seem to be somewhat independent of the macro-sculpture, for they bend upward more gradually toward the sides, so that if faint they cut across the threadlike lirae, or if strong, interrupt them. They may also be greatly contorted, locally, in the spaces between the lirae. The lirae themselves are not rigid but pursue a somewhat irregular course; in places they may be much confused. Finally, the surface is regularly marked off into broad concentric bands by low imbrications marking growth stages. This is clearly shown by one specimen but is probably present in some degree on all.

Hall and Clarke describe the shell as relatively thick. As observed by me it is relatively thin, if the large size of the species is duly considered; consequently most specimens are more or less crushed. They also describe the surface as covered with low, rather faint and distant concentric lines or wrinkles. This does not accurately describe the sculpture of well-preserved specimens, and I judge that the holotype was slightly worn or slightly exfoliated. The markings in nature are really sharp. They are of course superficial and may be completely obliterated by exfoliation. Hall and Clarke also mention fine radiating lines on the inner laminae, and these are shown by some of my specimens also, especially over the posterior parts. On the other hand, some external molds indicate the presence of radial markings on the exterior. These may take the form of numerous fine irregular discontinuous incised lines, which are chiefly developed on the anterior half of the shell and are to some extent connected with contortions in the growth lines, or they may appear as a very fine, rather regular fluting near the margin. No muscle scars are shown by my specimens, but several show the false cardinal area as sharply defined and slightly elevated above the floor of the valve, fairly broad even in the dorsal valve, and much broader in the ventral valve. In both valves the area is marked by transverse striae; in the ventral valve it is bisected by a long, narrow groove (the pedicle furrow), which tapers appreciably backward. Furthermore, in this valve the "cardinal area" is not formed by a mere thickening of the shell, as it appears to be in some Lingulas, but by an overarching wall with a deep recess beneath it.
The shell substance in certain layers has the appearance of being very finely punctate. This should, of itself, relegate the species to the genus Lingulipora, if the appearance of punctate structure is decisive. The inorganic layers of all Lingulas are thought tc be finely punctate, and consequently the distinctive character of Lingulipora may be a difference in degree of coarseness or an accident of exfoliation which would expose or fail to expose such a layer. It may be best to regard this character as of specific but not of generic importance.

Hall and Clarke do not compare Lingula flabellula with any other species, but it is in fact closely similar to $T$. waverlyensis - not of course to $T$. waverlyensis as they identify it but to the species as represented by Herrick's figures. L. fabellula as figured is somewhat larger than $T$. waverlyensis and somewhat more ovate in shape owing to its deeply arcuate anterior outline. The figure, however, is said to be inaccurate in that respect, and my specimens seem to show that the two species do not differ materially in shape. They would, from the descriptions, appear to differ materially in their surface characters, but the description of this feature in T. flabellula appears to have been based on a specimen that was slightly exfoliated. T'ue specimens in my collection indicate that the two shells were ornamented in the same manner, though porsibly not on the same scale. The markings of $T$. waverlyensis appear to be a little coarser if they are accurately represented in Herrick's figure, in which only abc ut 6 lirae occur in 5 millimeters. No specifications are given in the description except for his statement that the species is more finely marked than Meek's (on what grounds we are not informed). Meek's figure represerts 8 lirae in the space of 5 millimeters-which Meek seys is too many. The beds at Sciotoville which furnish T. flabellula occur about midway in the Cuyahoga shale, on information given by my good friend Wilber Stout. $T$. waverlyensis, therefore, occurs at a considerably higher horizon-the shale above conglomerate II. For the present, at least, it seems advisable to retain both species as valid. The $T$. waverlyensis of Hall and Clarke is also to be considered a distinct species provisionally; in fact, it appears to possess more solid claims for distinction from authentic $T$. waverlyensis than does $T$. flabellula. It closely resembles the $T$. scotica? of Meek and also the T. casteriana of th is paper; all three of them may prove to be the same sfecies.

Horizon and loeality: Midway in the Cuyahoga shale, Sciotoville, Ohio (station 718 ).

\section{Trigonoglossa irvinensis (Foerste) Girty}

$$
\text { Plate 9, figures 30-39a }
$$

?1888. Lingula melie. Herrick, Denison Univ., Sci. Lab., Bull., vol. 4, pl. 9, fig. 1. Bedford shale, Central College, Ohio.

?1889. Lingula melie. Herrick, Am. Geologist, vol. 3, pl. 4, fig. 1. Bedford shale, Ohio. 
?1895. Lingula melic. Herrick (part). Ohio Geol. Survey, Rept., vol. 7, pl. 20, fig. 1 [not pl. 22, fig. 10]. Bedford shale, Central College, Ohio.

1909. Lingula irvinensis. Foerste, Ohio Naturalist, Vol. 9, No. 7, p. 517, pl. 1, fig. 7. Bedford-Berea zone, Irvine, Ky.

Shell small, acuminate-ovate in outline, widest below the middle; width about two-thirds to three-fourths of the length. The two valves are much alike in shape and are distinguished in the usual manner, the dorsal valve being somewhat rounded at the posterior extremity, the ventral valve more poimted.

The surface is marked by strong, sharply elevated, rather regular and somewhat distantly spaced concentric lirae, some of which at fairly regular intervals are more prominent than the rest and mark stages of growth. Over the more nrarginal parts the lirae may become thick and round and the striae narrow.

A false cardinal area is well shown by some dorsal valves, and a corresponding structure is doubtless present in the ventral valve. Shell structure finely punctate.

This species is abundant in the Bedford shale of northern Obio, and the foregoing description is based upon specimens from that region. It shows considerable variation in all its characters. Some specimens reach 13 millimeters in length; very few are larger. The shape also varies, some specimens being proportionally broader than others. The ornamentation typically consists of regular, sharply elevated concentric lirae separated by relatively broad, flat interspaces, but specimens manifest a tendency to deviate from this to one consisting of rather strong, rounded, somewhat irregular, more or less crowded lirae.

Most specimens differ distinctly in color from the enclosing rock. The prevailing color is a rather light brown, ranging in different specimens from almost cream-colored to very dark, and concentrically banded with a dark bluish gray. As a rule the gray tints are subordinate, but they may dominate the entire surface.

The same species, or one very similar to it, occurs in the red Bedford shale at Central College. My specimers from Central College are all small, about 7 millimeters im length, but except for their smaller size, they agree well enough with the form from Bedford and the other localities in the north. I found two species of linguloid shells at Central College-Trigonoglossa irvinensis, as here identified, and Lingula herrickana, n. sp., of these pages; of these, T. irvinensis is much more abundant. Herrick found only a fragmentary specimen at the same horizon and locality, and he identified it as Lingula melie, restoring it to match. The fragment itself (it consists of the anterior fraction of the shell) has a length of nearly 7 millimeters, and the restoration a length of 10 millimeters. On the basis of my census Herrick's specimen should belong to $T$. irvinensis, but it is much larger than any of my specimens, and as restored it has not the right shape for L. herrickana. As the case now stands he must have had a specimen of $T$. irvinensis considerably larger than any of mine, or a specimen of the rare $L$. herrickana which he wrongly restored, or a specimen of a species that I did not find at all.

If Herrick's form proves to be conspecific with the one under consideration (a relation which can be ascertained only by an examination of his specimen, especially as he gave only a figure without any descriptive matter), it is certainly not $L$. melie, not only beca'ss? of a difference in shape but more decisively because $c^{f}$. a difference in sculpture. The sculpture, would als? be decisive as between $T$. irvinensis and L. herrickanc, irrespective of the shape, the restoration of which would be more or less speculative.

The same species, apparently, occurs again in the Bedford fauna at Irvine, Ky., where it was describer as Lingula irvinensis. Foerste's holotype is a small shell, barely 6 millimeters in length, and apparently a dorsal valve. My specimens from Irvine also are small, the largest but little more than 7 millimeters in length; in size and other characters they agree essentially with the specimens from Central College. Tho sculpture consists of delicate raised lines separated by much wider flat interspaces. The scale of these markings seenrs to be somewhat finer than that of the specimens from northerm Ohio, but the shells themselves are only about half as large. Some differences in detail can also be recognized between the specimena from Irvine and those from Central College, but th? detail is shown only by a few specimens, and it differs sonrewhat on each.

The specimens from northerm Ohio have so much the size and shape of the Lingula meeki of Herrick as to raise a doubt whether he may not have been dealing with the same species; if so, the name should be changed from $T$. irvinensis to $T$. meeki, for Herrick's name long antedates Foerste's. Lingula meeki, however, was found, according to Herrick, associated with $L$. atra and $L$. cuyahoga (see p. 13 of Herrick's paper of 1888), whereas no species at all similar to $L$. atra and $L$. cuyahoga are associated with $T$. irvinensis; furthermore, the horizon of $L$. meeki and the associated Lingulas i in the Cuyahoga shale. Finally, L. meeki is said to be "mrarked with the usual concentric striae" (like L. atra, L. melie, L. cuyahoga et al.?) This is certainly not true of $T$. irvinensis and would hardly have been written of $L$. meeki, one would imagine, if $L$. meeki differed appreciably from its associates.

Of species from the typical Mississippian faunas, $T$. sedaliensis is somewhat comparable to T. irvinensis. A comparison with specimens loaned by the Walker Museum of the University of Chicago indicates that the Bedford form is distinct in its own characters as well as occurring in an older and very different fauma. $T$. sedaliensis is larger and has a wider cardinal angledifferences shown by Weller's figure of that species; there are also slight differences in shape. However, $T$. 
irvinensis varies, so that some specimens approach $T$. sedaliensis, if not in size or in spread, at least in other features of configuration; many are widely different. In point of sculpture the two species are much alike. The concentric lirae are about equally spaced in both, but while they are thin and sharp in some specimens of $T$. irvinensis, as they are in the Chouteau form, in others they are thicker and lower and show a tendency to degenerate into low, fine undulations such as are not found in $T$. sedaliensis until a much larger size is attained, if at all.

$T$. irvinensis might be interpreted as being a small form or an immature stage of some of the large Mississippian Trigonoglossas, such as $T$. flabellula, but this possibility can hardly be seriously entertained. $T$. irvinensis is fairly abundant in the Bedford shale of northern Ohio, where the largest specimens are found, but it is invariably a small shell and a mature one, if indeed there is any evidence for determining that condition besides uniformity in size.

Some years ago I introduced Lingulipora as a generic term for Lingulas which have a punctate structure. If that were the only consideration, $L$. irvinensis should be referred to Lingulipora instead of to Trigonoglossa. The specimens of $T$. sedaliensis mentioned above likewise show a punctate structure, the punctae being fine and rather scattered. Furthermore, I reported this structure as present in $T$. nebraskensis, which later was made the genotype of Trigonoglossa, my observations being made on specimens from the Wewoka formation. Dunbar and Condra, on the other hand, say that their specimens of $T$. nebraskensis are impunctate. I have reexamined my specimens from the Wewoka formation, and though some of them are seemingly impunctate (for instance, the specimen figured), one of them at least in a suitable light shows a very fine punctation. That Trigonoglossa may have a punctate structure seems fairly certain, for the present species comes within the boundaries of Trigonoglossa if Trigonoglossa has any boundaries at all and some specimens of $T$. irvinensis are unmistakably punctate, although others, indeed most others, are doubtful or worse. Why some specimens of a species should be clearly punctate and others apparently not and what significance in classification should attach to the character are matters problematic.

If the shell of Paleozoic Lingulas was constructed like that of living ones, it was made up of layers of phosphatic material having a fibrous structure which alternated with layers of calcareous material traversed by microscopic canals; it may be that where the one layer is exposed to view the shell appears to be punctate and where the other layer is exposed, impunctate. As the type species of Lingulipora has more the shape and sculpture of the common Paleozoic Lingulas (not to mention several punctate Lingulas cited by Hall and Clarke) and as some shells that have the shape and sculpture of Trigonoglossa certainly appear punctate, it is obvious that these Lingulas do not separate along the same lines when the division is based upon shell structure as when it is based upon shape and sculpture. The character of the shell, whether punctate or impunctate, has always had an important place among generic distinctions for the brachiopods, and it would appear at first that that should be made the plane of cleavage for the Lingulas as well as for other groups. It is questionable, however, whether the punctate feature in the Iingulas is justly comparable to the punctation in other brachiopods, for in other brachiopods the shell is of uniform composition and is, roughly speaking, punctate through its entire thickness except for callus which may partly cover the inner surface, whereas in Lingula the structure is, as above outlined, quite different. For this reason I am referring Lingula irvinensis under Trigonoglossa instead of Lingulipora and incline to the opinion that the latter genus was not well founded.

Horizon and locality: Bedford shale, Bedford (station 721), Brandywine Creek (station 722), Berea (station 723), Blue Rock Springs (station 952), Euclid (station 953), Doane Brook, and Central College (stations 726 and 726a), all in Ohio; Irvine, $\mathrm{Ky}$. (station 8085).

Trigonoglossa casteriana Girty, n. sp.

Plate 9, figures $40-41$

?1875. Lingula scotica? Meek, Ohio Geol. Survey, Paleontology, vol. 2, p. 276, pl. 14, fig. 9. Waverly g־oup, Ohio. ?1892. Lingula waverliensis Hall and Clarke, New York Geol. Survey, Paleontology, vol. 8, pt. 1, pl. 4K, fig. 7 [not L. waverlyensis Herrick]. Waverly sandstone, Oil City, $\mathrm{Pa}$.

Shell of medium size for the genus, much longer than wide, subcuneate or subovate in shape, with the front broadly rounded and the strongly diverging sides faintly arched. Length about $1 \frac{1}{2}$ times the breadth (1.4 in one of the type specimens and 1.6 in the other).

Surface marked by thin, regularly arranged concentric lirae rising abruptly from flat interspaces four or five times their width. The interspaces, if not entirely smooth, are marked only by obscure incremental lines. From 10 to 14 lirae occur in a space of 5 millimeters.

The apparent relations of the different forms of Trigonoglossa described in the †Waverly fauna of Ohio, are discussed elsewhere in this paper in connection with T. flabellula. It is there noted that the form figured by Meek as Lingula scotica? and the form figured by Hall and Clarke as L. waverlyensis from Oil City, Pa., are strikingly similar in shape and may be ccnspecific. They are also very similar to the species here described as T. casteriana, and these two citations are included in the synonymy. This treatment, however, is only provisional, as I have not seen the originals of either form. Furthermore, both species seem to be more coarsely marked than T. casteriana; Hall and Clarke's specimen, if accurately figured, has about 8 lirae in 5 millimeters, 
and Meek's about the same. In the first instance the difference is not so great as in the second, for Meek remarks that in his figure the lirae are too crowded. The lirae of T. casteriana are spaced much like those of T. flabellula. The lirae of T. flabellula, however, are much more delicate, in spite of the fact that they are known from testiferous specimens or from impressions in a matrix of very fine texture, whereas those of $T$. casteriana are known from impressions in sandstone and from shells of smaller size besides.

It is difficult to weigh in terms of taxonomy the differences which these forms actually show, and their proper differences should be weighed in the light of their stratigraphic occurrence. The three forms, $T$. casteriana, T. scotica?, and T. waverlyensis Hall and Clarke (not Herrick), differ from each other slightly in shape, but from T. waverlyensis, to which one of them was referred, they differ, one and all, in being narrower and less cuneate. T. casteriana occurs at a much lower horizon than typical $T$. waverlyensis and at a somewhat lower horizon than typical $T$. flabellula, for typical $T$. casteriana occurs in the Corry fauna or below, whereas $T$. waverlyensis occurs near the top of the tWaverly group, and $T$. flabellula near the middle of the Cuyahoga shale. T. flabellula, which in geologic age is nearest to T. casteriana, is a larger and broader shell, and in these differences it seems rather constant. Of the two species which resemble T. casteriana in shape and proportions, Meek's specimen identified as $T$. scotica? is said by Weller to have come from the Berea sandstone at Berea, Ohio, though I believe through a misunderstanding. The authority is certainly not Meek's. If it does, however, it must be nearly of the same age as the cotypes of $T$. casteriana (if they occur in the Corry fauna). One of the original cotypes of $T$. flabellula is also reputed to have come from the Berea sandstone at Berea; it has a decidedly different shape from Meek's specimen, and consequently from $T$. casteriana. The horizon of the T. waverlyensis of Hall and Clarke cited from Oil City, Pa., is uncertain; it may be younger but hardly older than $T$. casteriana.

In addition to the specimens found near Warren, Pa., I am provisionally including in $T$. casteriana two specimens from Union City. One agrees very closely with the smaller cotype; the other is considerably shorter and broader, but it evidently owes this shape in part to pressure. These specimens came from a lower horizon than the cotypes. A specimen similarly broad is associated with the cotypes, but it likewise has been deformed by pressure. A very fragmentary specimen obtained near Benzinger, in Elk County, Pa., apparently in the Cattaraugus formation, is also included under this species pending the discovery of specimens that are more definitely identifiable.

In the Mississippi Valley the species most comparable in its own characters and in geologic age is $T$. sedaliensis, but extended comparisons hardly seem profitable. The type specimen of $T$. sedaliensis is very imperfect, and as restored by Weller it represents a broader and more cuneate species. I have been able to make comparisons with the Chouteau form partly through specimens in my own collection and partly through specimens kindly loaned by the Walker Museum of the University of Chicago. These, if they actually belong to $T$. sedaliensis, reach a length of 20 millimeters and a width of 15 millimeters and have a shape more slender than the holotype as restored. They are somewhat smaller than $T$. casteriana and have somewhat more numerous and crowded lirae. According to Weller the holotype has 20 or more lirae in a space of 5 millimeters, but this measurement must necessarily have been made back of the middle, where they would be somewhat more closely arranged than near the front.

Horizon and locality: Undetermined horizon, 4 miles soutrwest of Warren, 1 mile northwest of Union City, and cliffs $4 \frac{1}{2}$ miles northwest of Union City; Cattaraugus formation (?) cut on the Pennsylvania Railroad about $1 \frac{1}{2}$ miles east of Benzinger (station 3526), all in Pennsylvania.

\section{Trigonoglossa sp.}

\section{Plate 9, figures $46-47$}

Shell small, a length of 12 millimeters being about the maximum observed. Outline elongate ovate, more or less acuminate. Convexity rather strong.

Surface somewhat coarsely and irregularly striated. In some specimens the raised elements or lirae tend to be subangular and more regular than in others, and one specimen is marked by thin lirae regularly spaced and rather far apart. One specimen also shows fine obscure radiating wrinkles or, perhaps better, a few narrow radiating grooves. Shell substance finely punctate.

The specimens included here differ markedly in corvexity, some of them being exceptionally convex for linguloid shells. They do not show the usual distinction between dorsal and ventral valves, and it is most irrprobable that the valves are distinguished by this difference in convexity.

The relations of this species are extremely uncertain, and they depend primarily on whether it belongs to Lingula, as commonly interpreted, or to Trigonoglossa. In point of shape it might belong in either. The main distinction of Trigonoglossa is its sculpture, and with one exception these specimens do not have the sculpture of Trigonoglossa in its typical development, though some appear to have that sculpture in a modified form. The sculpture, on the other hand, is markedly differer.t from the very fine, very sharp, and very regular stric,tion of many of our Carboniferous Lingulas.

This form occurs associated with T. flabellula, and the natural supposition would be that it represents but an immature stage of the larger species. The largest, specimen of the present form, however, is only 12 
millimeters in length and the smallest specimen of $T$. fabellula in the collection is not less than 30 millimeters in length; neither species is exactly rare. Another circumstance that may bear upon this point is that most of the small specimens retain both valves in conjunction, whereas only one of the large specimens does so. There is also a difference in sculpture, rather marked in some specimens, nonexistent in one. It might be contended that the latter was a young specimen of $T$. flabellula and the others not. At best the evidence is not conclusive that these small shells are not T. flabellula in an inmature stage.

There is an apparent contradiction between the statement just made that in many specimens the valves occur in conjunction and a previous statement that it has not been possible to distinguish between them in the usual manner, by the shape of the posterior end. As a matter of fact, where the valves occur together they are skewed, deflected, and broken, so that the posterior end of only one of them is shown.

A much better case can be made out for identifying these specimens with $T$. irvinensis. No material or constant difference in size or shape is apparent. The specimens of $T$. irvinensis are less convex, but they may have been compressed, and they generally possess the characteristic Trigonoglossa sculpture, which is distinct in but one specimen from Sciotoville.

Among the Carboniferous species still remaining under Lingula the Lingulas from Sciotoville are especially comparable to $L$. melie and $L$. meeki. $L$. melie in its typical form can be dismissed with a few words; it is a smaller and more elongate species. On the other hand, these shells from Sciotoville so closely resemble L. meek $i$ in size and shape that I at one time identified them with that species. Of the surface characters of L. meeki, Herrick merely says that they consist of "the usual concentric striae." If he means exactly that $L$. meeki is marked like L. atra, L. cuyahoga, and other species of Lingula that he distinguished, the shells from Sciotoville can hardly be $L$. meeki. Now Herrick is rather vague about the locality and horizon of $L$. meeki, and his remark about the surface ornamentation is also vague, inasmuch as he also referred to Lingula not only the species just mentioned but also his waverlyensis, at present regarded as a typical Trigonoglossa. In his original description of L. meeki, Herrick cites it from the Cuyahoga Valley (which is not very specific), associated with $L$. cuyahoga, L. atra, etc. L. atra, however, is said ${ }^{3}$ to be abundant above the juncture of the Little Cuyahoga with the Cuyahoga River, where it is associated with $L$. cuyahoga and L. meeki. This locality is in the Akron quadrangle, about a mile

3 Herrick, C. L., Denison Univ., Sci. Lab. Bull., vol. 4, p. 17, 1888. in a direct line from the Cuyahoga Falls, and the horizon is in the Cuyahoga shale. I have a collection from what I take to be the same locality, and neither that collection nor any other that I have from the Cuyahoga shale contains any Lingula which has the markedly ovate shape of $L$. meeki, whereas that shape exactly fits $T$. irvinensis, a species which in northern Ohio I have found only in the Bedford shale. The fauna of the Bedford shale as figured by Herrick is that which occurs in central Ohio, at Central College, but he was not wholly unacquainted with the formation as it is represented in the northern part of the State, for he says that several of the same species are abundant in Summit County near Peninsula, which, by the way, is also in the Cuyahoga Valley. Suspicion is thus aroused whether Herrick's specimens may not really lave come from the Bedford shale and whether his L. meeki is not the T'. irvinensis of this report. An examination of the type specimen might decide the matter.

Horizon and locality: Midway in the Cuyahoga shale, Sciotoville, Ohio (station 718).

\section{REGISTER OF LOCALITIES}

718. Midway in the Cuyahoga shale, right bank of the Ohio River at and for 1 mile above the mouth of the Little Scioto River.

721. Base of the Bedford shale, Bedford, Ohio.

722. Near the middle of the Bedford shale, Brandywine Creek, just below the falls, Cuyahoga County, Ohio.

722b. Same, at the base of the formation.

723. Bedford shale, in bed of Stony Creek, about 7 miles northeast of Berea, Ohio.

724. Bedford shale, layer immediately overlying the Cleveland shale, Berea, Ohio.

726. Bedford shale, Central College, Ohio, just above the blue shale in the bank, east side of Big Walnut Creek.

726a. Bedford shale in the "Red Hills" opposite Central College, Ohio, 5 feet above the Huron (?) shale.

952. Base of the Bedford shale, Blue Rock Springs, Cleveland, Ohio.

953. Base of the Bedford shale, Euclid, Cuyahoga Co'nty, Ohio. 3354. Small quarry about 1 mile south of Union City, Pa., probably in the Venango group of I. C. White.

3492. Along the Buffalo, Rochester \& Pittsburg rail ־oad about three-fourths mile north of Bingham, Pa., 70 feet below the Olean conglomerate member of the Pottsville formation.

3526. Cattaraugus formation (?), cut on the Pennsylvania Railroad about $1 \frac{1}{2}$ miles east of Benzinger, $\mathrm{Pa}$.

3552. Chagrin shale, about 50 feet below the Cleve'and shale, Paines Creek, Cuyahoga County, Ohio.

3553. Chagrin shale, Big Brook, Orange Township, Cuyahoga County, Ohio.

3555. Chagrin shale, 15 feet below the top, Brecksville, Cuyahoga County, Ohio, in the bed of Chippewa Creek.

3556. Top of the Chagrin shale, bed of Tinkers Creek, Bedford, Ohio.

8085. Bedford shale, just above the black shale, base of Minerva Mountain east of Irvine, Ky. 
PLATE 9 


\section{PLATE 9}

F'IGURES 1-4. Lingula arcta Girty, n. sp. (p. 47).

1. A nodule containing parts of four specimens.

1a. The most complete specimen on the slab, supposed to be a dorsal valve.

2. A somewhat crushed specimen which shows the sculpture of sharp but exceedingly fine striation.

3. A ventral (?) valve from Union City, Pa., referred to this species.

4. An imperfect specimen from Warren, Pa., referred to this species.

The original of figures 1 and $1 \mathrm{a}$ is from the Chagrin shale at Bedford, Ohio (station 3554). The original of figure 2 is from the Chagrin shale at Brecksville, Ohio (station 3555). The original of figure 3 is from Union City, Pa., and probably from a horizon in the Venango group of I. C. White (station 3354), and the original of figure 4 is from an unknown horizon near Warren.

Figures 5-9. Lingula eriensis Girty, n. sp. (p. 48).

5. An elongate dorsal valve, from shale.

6. A dorsal valve from a nodule.

7. A ventral vale from a nodule, partly exfoliated.

8. A dorsal and a ventral valve of the same specimen but with diverging axes; from a nodule.

9. A specimen of doubtful affinities preserved as a mold in sandstone.

The originals of figures 5, 6, and 7 are from the Chagrin shale at Brecksville, Ohio (station 3555); that of figure 8 is from the Chagrin shale at Bedford, Ohio (station 3554). The original of figure 9 is from an undetermined formation near Bingham, Pa. (station 3492).

Figures 10-12. Lingula limatula Girty, n. sp. (p. 50).

10. A slightly imperfect specimen showing the shape.

11. Part of the surface of another specimen from the same locality.

12. A large specimen provisionally referred to this species.

The originals of figures 10 and 11 are from the Venango group of I. C. White at Union City, Pa. The original of figure 12 is from the Chagrin shale at Brecksville, Ohio (station 3555).

Figures 13-14. Lingula herrickana Girty, n. sp. (p. 51).

13. Squeeze from an external mold of a ventral (?) valve. The external mold shows regular but exceedingly fine concentric striae.

14. A dorsal (?) valve.

The two figured specimens are from the Bedford shale at Central College, Ohio (station 726a).

Figdres 15-18. Lingula papyracea Girty, n. sp. (p. 49).

15. A specimen macerated and flattened in shale.

16. A large specimen similarly preserved.

17. A ventral (?) valve.

18. A dorsal valve.

18a. Posterior end of the same. The latest additions to the shell have surrounded what was originally a terminal beak.

The originals of figures 15 to 18 are from the Bedford shale at Bedford, Ohio (station 721).

Fig URes 19-24. Lingula randalli Girty, n. sp. (p. 51).

19. A broad specimen supposed to be a dorsal valve.

20. An exceptionally narrow ventral valve. It seemingly has suffered somewhat from lateral compression.

21. A ventral valve somewhat misshapen from compression. The surface ornamentation, which is excellently preserved, consists of very fine but sharp concentric striae.

22. A nearly perfect dorsal valve.

23. A dorsal (?) valve somewhat misshapen as a result of compression.

24. A small specimen associated with the large ones and regarded as an immature shell of the same species.

The originals of figures 19 to 24 are from an undetermined horizon near Warren, Pa. The original of figure 23 is from a different locality from the five others, which are all from the same locality.

Figures 25-29. Lingula ligea Hall? (p. 52).

Five specimens referred with doubt to Hall's species. They were found at the phyllocarid horizon, Warren, Pa. 


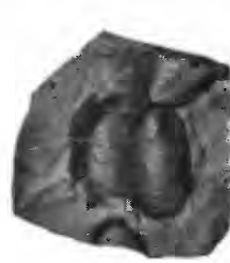

1 政
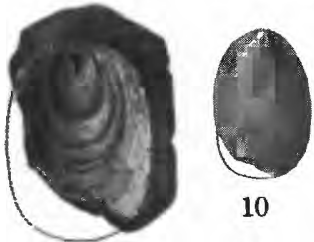

10

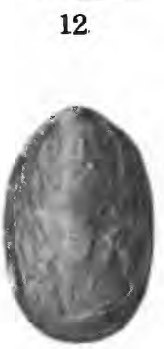

19

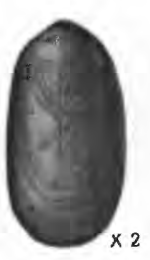

$1 a$

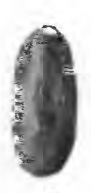

2
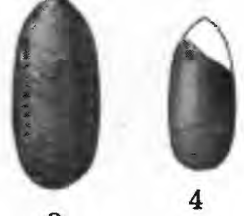

4

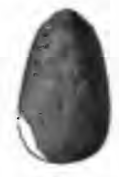

9

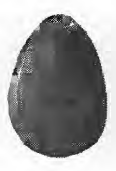

5

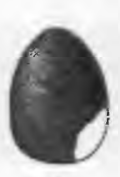

6

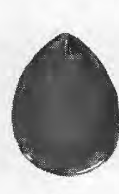

7

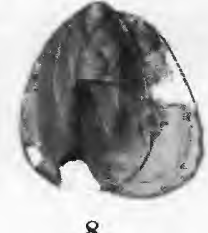

8
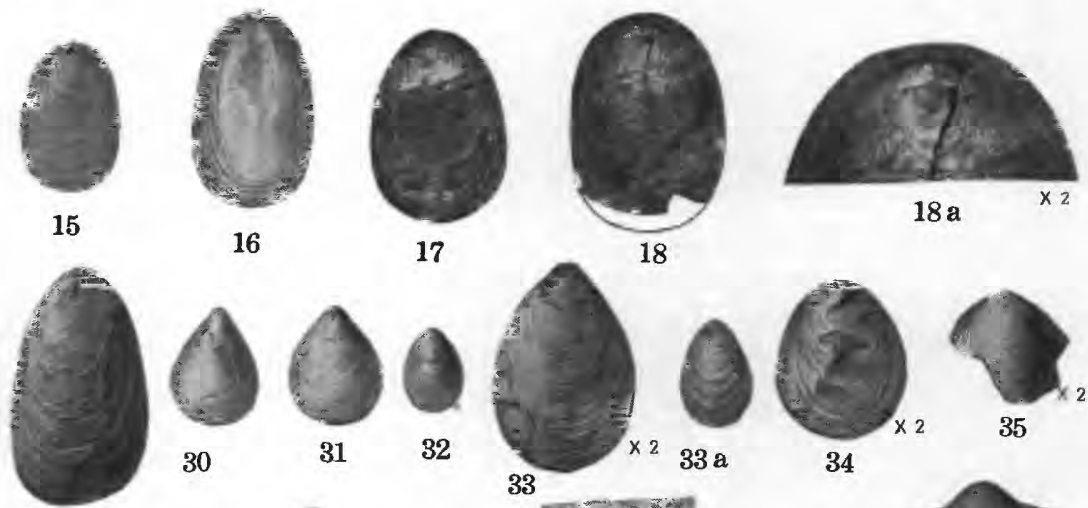

34
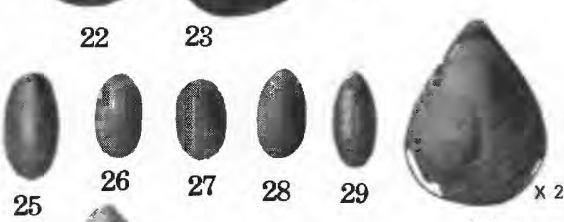

36
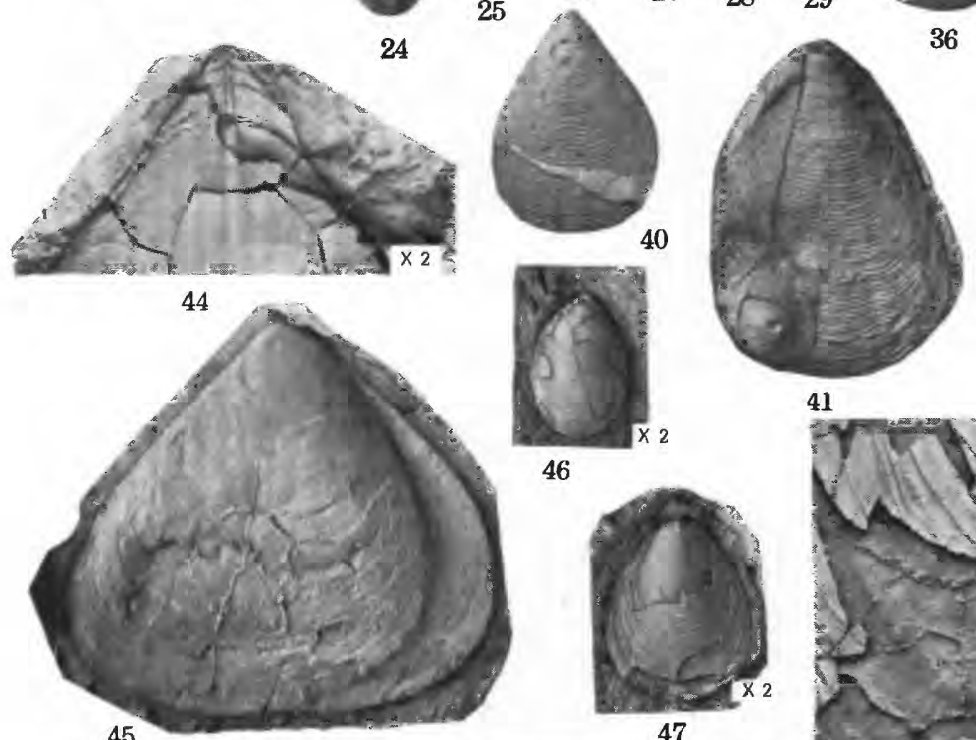

46

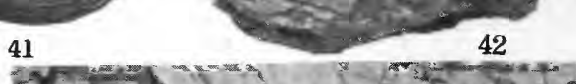

42
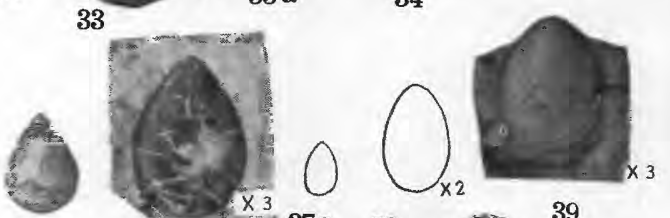

$36 \mathrm{a}$
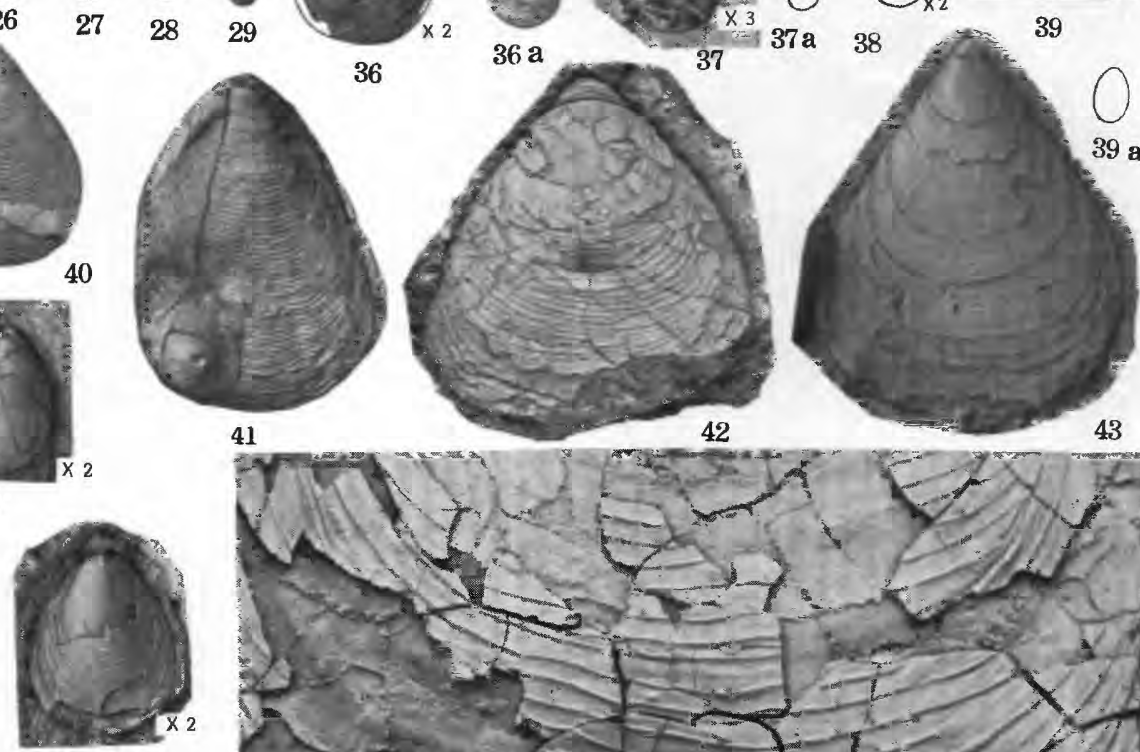

47

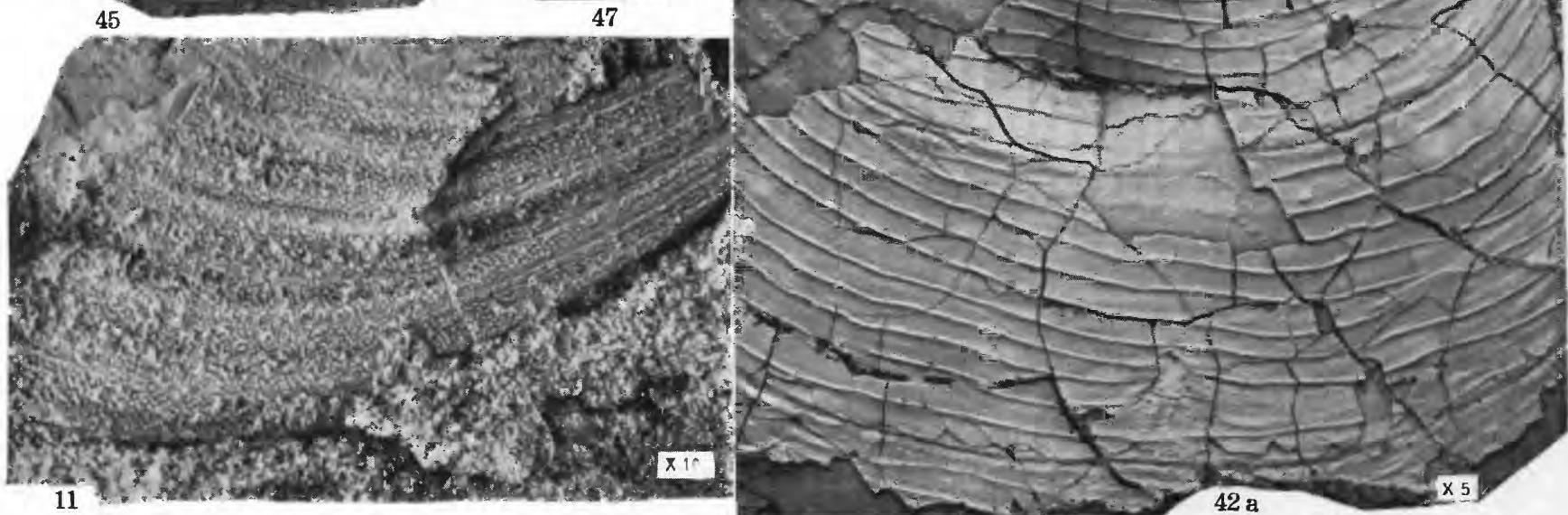

LATE DEVONIAN AND EARLY CARBONIFEROUS LINGULOIDS. 
FigUREs 30-39a. Trigonoglossa irvinensis (Foerste) (p. 58).

30. A ventral valve from which the shell has been largely exfoliated.

31. A somewhat broader ventral valve, also exfoliated.

32. A small exfoliated dorsal valve which shows well the punctate shell structure.

33. A dorsal valve which retains most of the shell.

33a. Same, natural size.

34. A fractured dorsal valve which shows the surface characters.

35. Posterior end of a dorsal valve showing detail of sculpture.

36. Internal mold of what appears to be a dorsal valve showing the large cardinal area.

36a. Same, natural size.

37. A much macerated ventral valve from Kentucky.

37a. Same in outline, natural size.

38. Outline of a dorsal valve from Central College preserved as an internal mold.

39. A dorsal valve from Central College.

39a. Same in outline, natural size.

The originals of all figures are from the Bedford shale or equivalent horizons. The originals of figures 30,31 , and 36 are from Euclid (station 953); that of figure 32 from Doane Brook; that of figure 33 from Berea (station 723); those of figures 34 and 35 from Brandywine Creek (station 722), all in northern Ohio; that of figure 37 from Irvine, Ky. (station 6686); and those of figures 38 and 39 from Central College, in central Ohio (station 726a).

Figures 40-41. Trigonoglossa casteriana Girty, n. sp. (p. 60).

40. Squeeze from a small ventral valve showing shape and sculpture. The original is a mold in sandstone.

41. Squeeze from a large dorsal (?) valve which has an Orbiculoidea attached to it.

The originals of figures 40 and 41 were found near Warren, Pa., and the horizon is possibly that of the Corry sandston?.

Figures 42-45. Trigonoglossa flabellula (Hall and Clarke) (p. 55).

42. A dorsal valve. The upper part is an internal nold and shows the large cardinal area.

42a. Part of the surface. Note the irregularity of the concentric lirae and how in places some of them are intercepted $k y$ others. The shell may be macerated, but it is decidedly thin.

43. Squeeze of a ventral valve. The delicate but distinct varices of growth should be noted.

44. Posterior end of a ventral valve preserved as an internal mold. The large cardinal area is partly concealed at the left $\mathrm{ky}$ the matrix, showing that there was a cavity between the shell that formed the cardinal area and the main part of $t] \cdot$ valve.

45. Squeeze of a specimen which retained both valves though skewed.

The originals of figures 42 to 45 are from the well-known locality at Sciotoville, Ohio, and the horizon is about midway in the Cuyahoga shale (station 718).

Figures 46-47. Trigonoglossa sp. (p. 61).

46. A dorsal (?) valve.

47. A ventral (?) valve supposed to be of the same species.

The originals of these two figures are from the same locality and horizon as the foregoing, midway in the Cuyahoga shale at Sciotoville, Ohio (station 718). 



\section{INDEX}

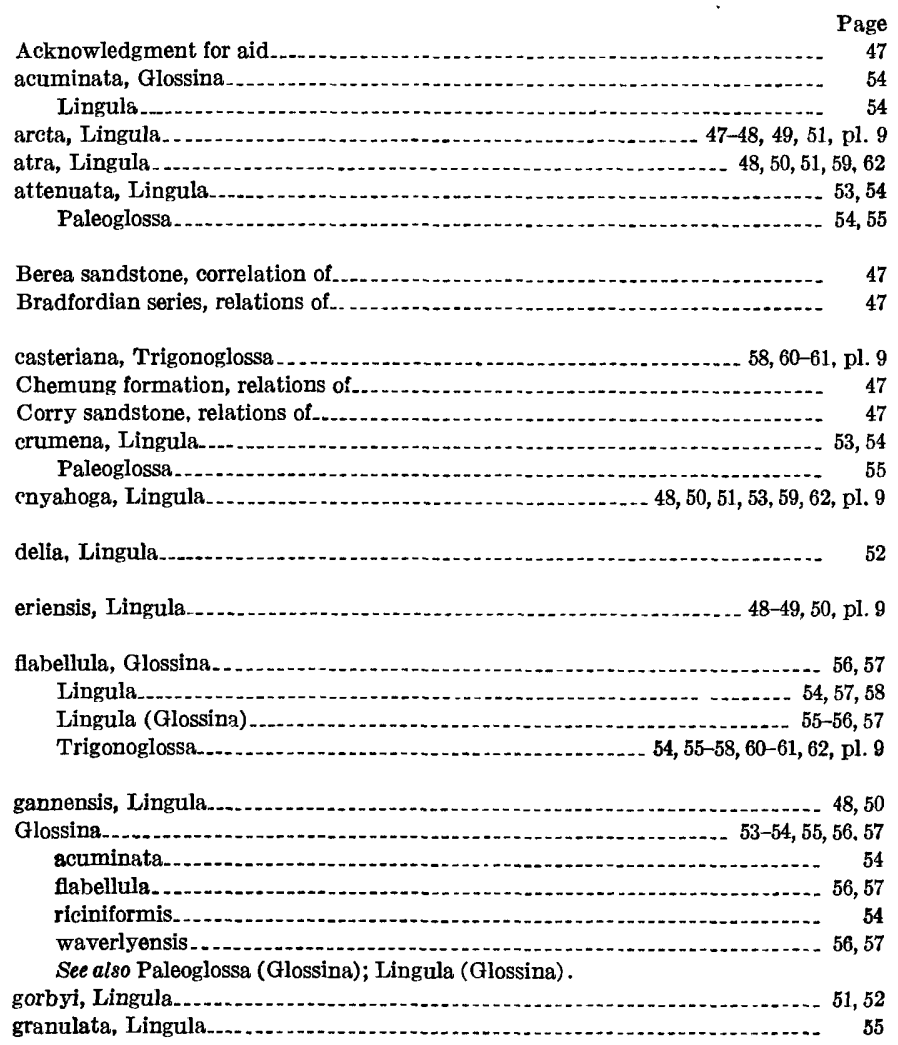

herrickana, Lingula

$48,51,59$, pl. 9

irvinensis, Lingula

$54,59,60$

Trigonoglossa

$49,51,55,58-60,62$, pl. 9

kentuckyensis, Lingul

Trigonoglossa

57

Kinderhook group, relations of 54,55

lamellata, Lingula

ligea, Lingula

limatula, Lingula.

Lingula.

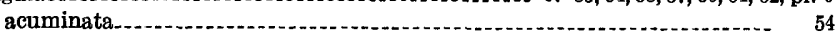

arcta.......... $47-48,49,51$, pl. 9

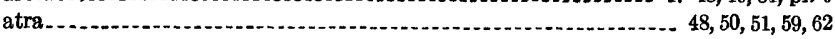

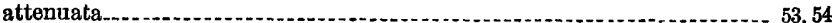

crumena

cuyahoga

delia.

eriensis

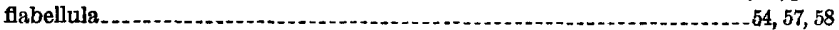

gannensis.

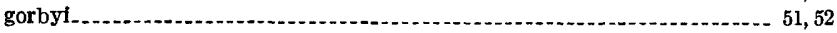

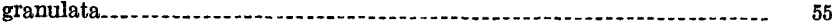

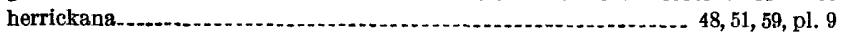

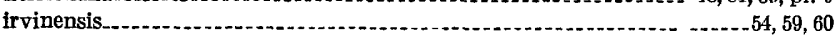

kentuckyensis_............... 57

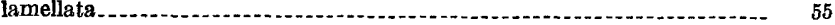

ligea

var

limatula

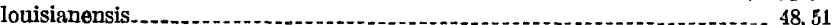

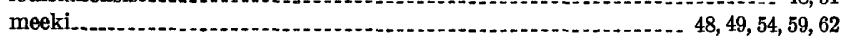

melie............... 48, $49,54,59,62$

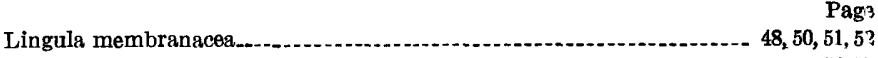

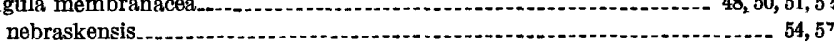

paliformis... papyracea_-_._. paracletus_................ 48, 4 ?

punetata_._._.

randalli._._.

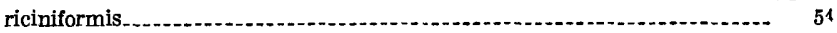
scotica....... $54,55,56,57,61$

var.

sedaliensis_............................ 54

spatulata............. 53

varsoviensis

sp., cf. L. cuyahoga.

Sp., cr. L. cuyahoga
(Glossina) flabellula

Lingulella........ 55

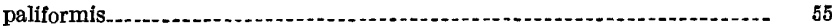

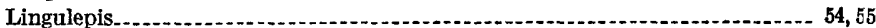

Lingulipora-

Localities, list of

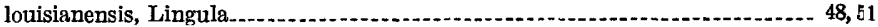

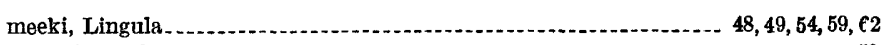

Trigonoglossa

melie, Lingula..................................................... 48, 51, 53,58-59, 62

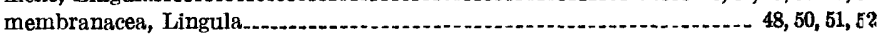

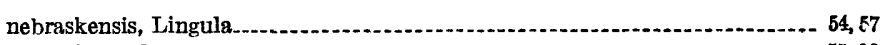

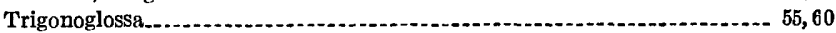

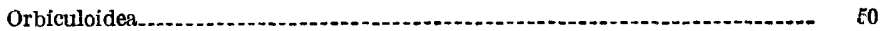

Paleoglossa. . . . attenuata_._.

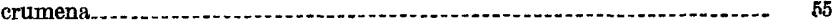

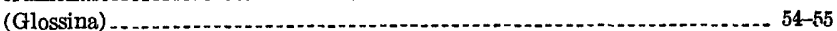

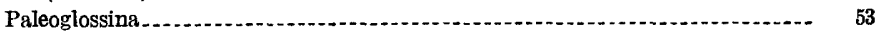

paliformis, Lingula

Lingulella...

Papyracea, Lingula ........................... 49-50, pl. 9

paracletus, Lingula_.

punctata, Lingula.

randalli, Lingula . . .

riciniformis, Glossina.............. 54

Lingula...... 54

scotica, Lingula.

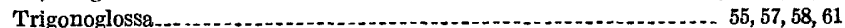

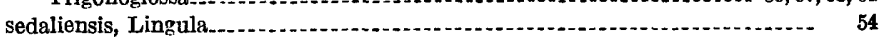

Trigonoglossa_...........

spatulata, Lingula

Syringothyris

Trigonoglossa_.

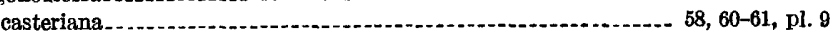

flabellula _ $54,55-58,60-61,62$ pl. 9

irvinensis ...................... 49, 51, 55, 58-60, 62 , pl. 9

kentuckyensis..................... 54

meeki .

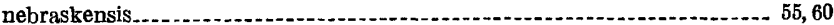

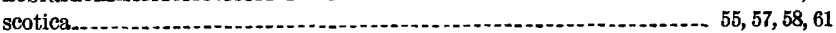

sedaliensis.

waverlyensis_....................................................... 54, 55, 58, 61

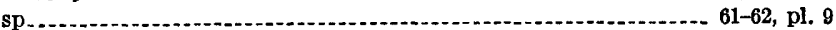

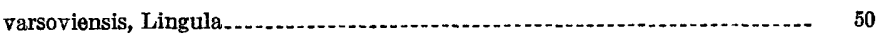

Waverly group, relations of
waverlyensis, Glossina.

Trigonoglossa 